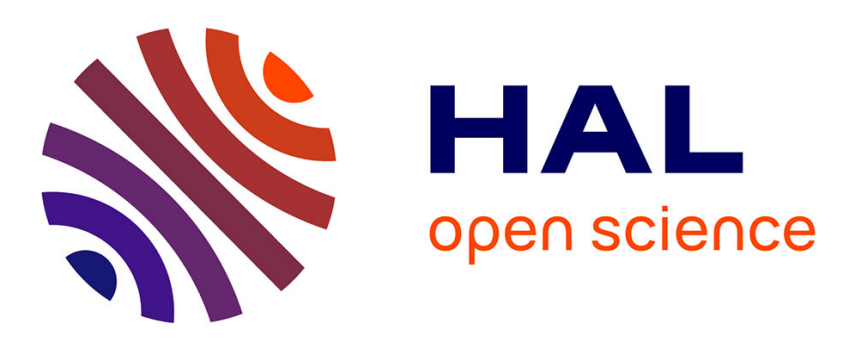

\title{
Eco-design of microbial electrochemical technologies for the production of waste-based succinic acid thanks to a life cycle assessment
}

\author{
A. Foulet, T. Bouchez, Elie Desmond Le Quemener, L. Giard, L. Renvoise, \\ Lynda Aissani
}

\section{To cite this version:}

A. Foulet, T. Bouchez, Elie Desmond Le Quemener, L. Giard, L. Renvoise, et al.. Eco-design of microbial electrochemical technologies for the production of waste-based succinic acid thanks to a life cycle assessment. Journal of Cleaner Production, 2019, 225, pp.1155-1168. 10.1016/j.jclepro.2019.03.231 . hal-02609327

\section{HAL Id: hal-02609327 \\ https://hal.inrae.fr/hal-02609327}

Submitted on 26 May 2020

HAL is a multi-disciplinary open access archive for the deposit and dissemination of scientific research documents, whether they are published or not. The documents may come from teaching and research institutions in France or abroad, or from public or private research centers.
L'archive ouverte pluridisciplinaire HAL, est destinée au dépôt et à la diffusion de documents scientifiques de niveau recherche, publiés ou non, émanant des établissements d'enseignement et de recherche français ou étrangers, des laboratoires publics ou privés.

$$
\text { Copyright }
$$




\section{Accepted Manuscript}

Ecodesign of microbial electrochemical technologies for the production of wastebased succinic acid thanks to a life cycle assessment

Amandine Foulet, Théodore Bouchez, Elie Desmond-Le Quéméner, Lucas Giard, Laure Renvoisé, Lynda Aissani

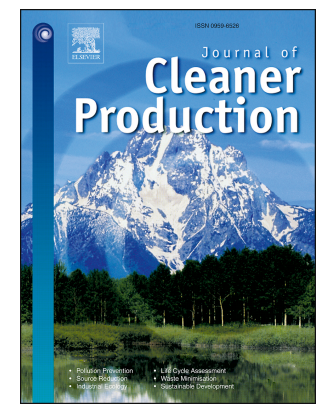

PII: S0959-6526(19)30940-0

DOI: https://doi.org/10.1016/j.jclepro.2019.03.231

Reference: JCLP 16235

To appear in: Journal of Cleaner Production

Received Date: 23 July 2018

Revised Date: 19 March 2019

Accepted Date: 21 March 2019

Please cite this article as: Foulet A, Bouchez Thé, Desmond-Le Quéméner E, Giard L, Renvoisé L, Aissani L, Ecodesign of microbial electrochemical technologies for the production of waste-based succinic acid thanks to a life cycle assessment, Journal of Cleaner Production (2019), doi: https:// doi.org/10.1016/j.jclepro.2019.03.231.

This is a PDF file of an unedited manuscript that has been accepted for publication. As a service to our customers we are providing this early version of the manuscript. The manuscript will undergo copyediting, typesetting, and review of the resulting proof before it is published in its final form. Please note that during the production process errors may be discovered which could affect the content, and all legal disclaimers that apply to the journal pertain. 
Ecodesign of microbial electrochemical technologies for the production of waste-based succinic acid thanks to a life cycle assessment

Amandine Foulet ${ }^{a}$, Théodore Bouchez ${ }^{b}$, Elie Desmond-Le Quéméner ${ }^{c}$, Lucas Giard ${ }^{a}$, Laure Renvoisé $^{d}$ and Lynda Aissani ${ }^{a, *}$
a. Irstea, UR OPAALE, F-35044 Rennes, France.
b. Irstea, UR HBAN, F-92761 Antony, France.
c. LBE, INRA, Narbonne, France.
d. Suez Environnement - CIRSEE, Le Pecq, France
* Correspondence to: lynda.aissani@irstea.fr 


\begin{abstract}
To face up abiotic resource depletion and other environmental issues as climate change due to usual fossil-based chemical production technologies, some alternative strategies have been developed using renewable resources. To produce such bio-based chemicals, renewable raw materials such as cereal crops or vegetables are currently used. To promote an environmental responsible practice, organic waste could be a relevant alternative to these dedicated crops. BIORARE technology is an innovative concept based on coupling an anaerobic digestion plant processing with bioelectrosynthesis in order to produce a range of chemicals from organic waste. Even if bioelectrosynthesis processes are not yet technologically mature; it is appropriate to consider the credibility of this emerging technology in environmental terms thanks to an eco-design approach.
\end{abstract}

This eco-design approach is based on the life cycle assessment (LCA) methodology. A LCA of biosuccinic acid production thanks to BIORARE technology has been carried out and has been combined with sensitivity analysis. The aim of this strategy is to ensure that sensitive parameters are identified and adjusted in order to make the technology the more eco-friendly possible whilst maintaining good economy efficiency. The present study describes the sensitivity analysis of the key parameters of the BIORARE technology applied for the production of succinic acid. These key parameters and their range of variation are chosen according to a realistic strategy allowing the control of the BIORARE technology on an industrial scale.

The results show that the current density applied during the bioelectrosynthesis and the hydrolysis yield during the pre-treatment of the waste stream are key parameters in the optimisation between production efficiency and the environmental footprint. The environmental efficiency of the process was studied by applying the eco-efficiency ratio. When the production of biosuccinic acid using the BIORARE technology was compared to a reference scenario, better overall eco-efficiency was shown despite some environmental penalties. In parallel, when the same study was performed for bioethanol production a low efficiency was revealed without environmental penalties.

Keywords: anaerobic digestion, LCA, eco-design, sensitivity analysis, eco-efficiency, biorefinery 


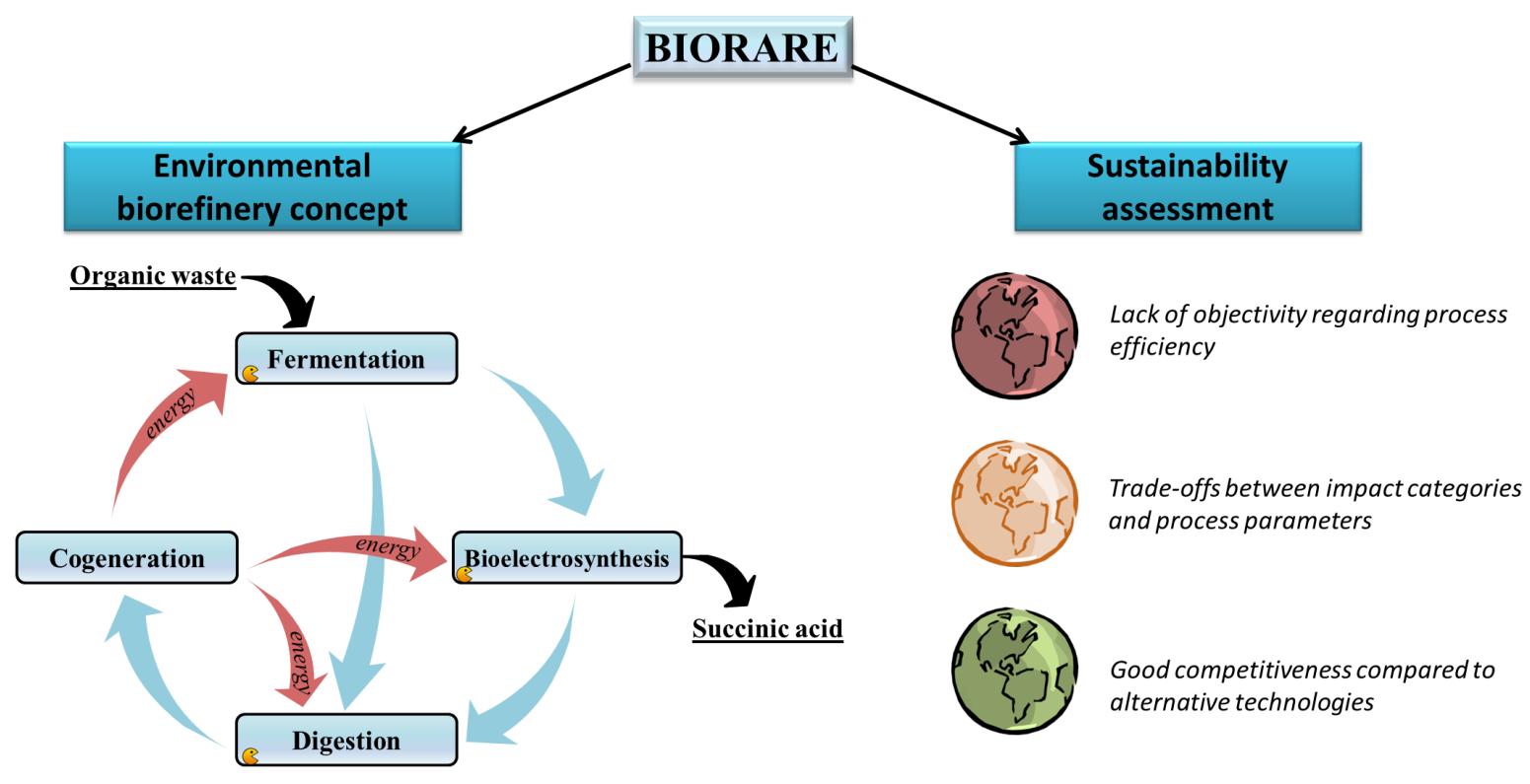




\section{Introduction}

The management of natural resources is a major topic of interest because it affects economic, social and strategic decision making. The way resources are being consumed generates substantial environmental concerns (Barnett and Morse, 2013). To lower mankind's environmental footprint, alternative energy sources have received special attention in recent decades. Resource depletion remains a major environmental issue which can be reduced by using waste streams as raw materials (European Commission, 2015). Anaerobic digestion (AD) is a renewable energy production following this approach. It is a natural biological process which biologically degrades organic matter in anaerobic environment (Nallathambi Gunaseelan, 1997). The products are methane $\left(\mathrm{CH}_{4}\right)$ and carbon dioxide $\left(\mathrm{CO}_{2}\right)$, also called biogas which can be burned to produce heat and electricity. $\mathrm{AD}$ is therefore recognized as an environmental friendly approach to produce green energy. Likewise, because of economic and environmental advantages, biological treatment of biowaste is of great interest for the production of a range of raw materials (Reddy et al., 2018).

In a further development, AD might be usefully combined with some emerging technologies (Yan et al. 2010; Ras et al. 2011; Fouilland et al. 2014; Escamilla-Alvarado et al. 2017) and especially with microbial electrosynthesis (also called bioelectrosynthesis or BES) (Beegle and Borole, 2018; Bhatia et al., 2018; De Vrieze et al., 2018; Foulet et al., 2018). This concept it at the heart of the BIORARE project which seeks to both generate electricity and produce useful chemical products from biowaste. This biorefinery concept employs a synergistic approach comprising waste treatment (applying anaerobic digestion) and chemical production (applying BES). By combining the two processes, BIORARE technology seeks to overcome disadvantages linked to the conventional production methods through single anaerobic fermentation, and to produce a useful chemical product and electricity while processing organic wastes. The BIORARE study is based on the theoretical coupling of BES to existing AD plants. Therefore, the actual system as considered does not yet exist. Consequently, since the process is based on largely theoretical knowledge (supported by limited study made at the laboratory scale), there is a need to establish its likely environmental credibility at a future full scale installation. To do so, a methodology based on process engineering and coupled with Life Cycle Assessment (LCA) is necessary. This approach, referred to as eco-design, enables the introduction of an environmental dimension in the design process which can help direct new processes towards a sustainable system.

LCA is a methodology that allows the quantification of the potential environmental impacts of a product or process through its life cycle, following ISO 14040 (2006a) and ISO 14044 standards (2006b). The multicriteria aspect of LCA when applied in research and development relating to a new product helps define the technological challenges with respect to the environment. Published data regarding the sustainability of bioreactors technology is rare. However, Foley et al. (2010) and Pant et al. (2011) demonstrate the usefulness of LCA on bioelectrochemical systems when applied to wastewater treatment. This scarcity of LCA case studies concerning such innovative technologies is due to the difficulty to reconcile the needs of LCA (robust industrial data and system modelling) and the characteristics of an emerging technology that is not yet fully developed (lack of robust industrial data and knowledge about the behaviour of the technology). However, this early development of an innovative technology is the right moment to perform a LCA in order to improve its environmental performances because it is still possible to make strategic environmental choices to finalize the technological development (Azapagic et al., 2006; Tsang et al., 2014). Therefore, the issues of such LCA are to succeed the system modelling with few data and knowledge and to produce useful LCA results to identify some strategic environmental choices. Concerning the BIORARE process, a LCA should be useful to identify the most environmentally friendly technological parameters and produced biomolecules to ensure the environmental relevance of this technology in a sustainable context. Some challenges will have to be met as design issues due to stream constraints to produce the targeted molecule and sensitivity analysis of relevant parameters at BES 
scale and at AD plant scale. In biomolecule production context, the design of the system should be based on the production constraints (nature and quantity of biomolecule). Thus the difficulty is to model the whole system with these constraints - it is not usual in LCA of AD plants with a modelling most often based on the quantity of treated waste. To carry out sensitivity analyses, the range of values of each tested parameter is needed. However, this knowledge of the technology's behaviour is missing for emerging technology. How to perform a robust LCA for BIORARE process? How to obtain useful LCA results to determine some strategic technological and environmental choices?

In this paper, the LCA approach for the environmental assessment of BIORARE process will be described in the section Method in highlighting the interest and the relevance of applying LCA through especially sensitivity analyses to support the development of the BIORARE process. Results of sensitivity analyses will be then presented and discussed to identify strategic choices of the intrinsic parameters value for BES (such as current density and inputs streams) as well as parameters relating to the AD plant, such as the waste hydrolysis efficiency and $\mathrm{CO}_{2}$ emissions management. Economical aspects will be brought in to the analysis by studying the economic performance of the technology as a function of its environmental performances by applying eco-efficiency estimation.

\section{Methods}

In this section, the BIORARE process is described by considering its components and their possible synergies. Amongst the possible application of BIORARE technology, is the production of alcohols (such as ethanol or 1,4-butanediol), organic acids, (such as succinic and formic acid), and caproate (Rabaey and Rozendal, 2010). For this study, succinic acid was chosen because of its role as a widely used intermediate product, (such as coatings, food and pharmaceuticals), also because of the increasing attention given to this product by the scientific community (Bechthold et al., 2008; Cao et al., 2013; Delhomme et al., 2009; Du et al., 2008; Lam et al., 2014; McKinlay et al., 2007).

\subsection{How to deal with a prototype system like BIORARE process using the relevant LCA}

\subsubsection{LCA of innovative technology issues}

The advancement of a technology can be measured against a scale such as that set out by the NASA Technology Readiness Levels (TRL) (Mankins, 1995). When a system is considered as early in its development, this is reflected by a low TRL (below 6). In the case of the BIORARE process, the basic principles have been established (TRL 1), the technology concept has been formulated (TRL 2), the experimental proof of concept has been validated (TRL 3), as well as laboratory tests (TRL 4), as set out by definitions used by the European Commission (European Commission, 2014).

In its early stages of development, pursuing a novel technology carries few risks. However such systems are not validated by demonstration nor an evaluation phase in a relevant and operational environment which means a lack of reliable data. This deficiency can be partly fulfilled with laboratory validation tests supported by relevant literature that strengthens the feasibility of the project. Based on theoretical studies, a new process should undergo different modelling approaches in order to simulate reality. This procedure also allows the identification of sensitive parameters which are difficult to analyse without experimental testing or LCA. Once such parameters are identified, a sensitivity analysis using LCA is important in order to understand their influence on the overall environmental profile of the process. By studying the environmental profile of a process prior to implementation, eco-design strategies can be applied at an early stage in order to limit the potential environmental burdens of a badly configured process (Azapagic et al., 2006). However it is difficult to select test values for such parameters and uncertainties come along this process (Gargalo et al., 2017). At this point, the opinion of reliable experts is necessary to define an appropriate range of values for all sensitive parameters. 
Most LCA studies evaluating innovative biotechnology have been conducted using lab scale data. It is important to scale up these results to an industrial operation because the experimental conditions can oversimplify the system. Such extrapolation is a difficult procedure that seeks to move from a scale of $1 / 10 \mathrm{~m}^{3}$ to one of several $\mathrm{m}^{3}$ or even a hundred $\mathrm{m}^{3}$ or more. Several studies in the LCA field propose strategies to scale up from lab or pilot scale to the industrial scale (Shibasaki et al., 2007). Other research proposes methodology for the use of LCA as a development tool within the early stages of research (Hetherington et al., 2014). LCA results based on lab-scale data can still be used to improve the technology early in its developmental phase, particularly when comparing options on its process set up (Tsang et al., 2014). However, when compared with processes assessed using industrial-scale data, the lab-scale evaluation will be inferior and less reliable. Thus the choice of representative input and output data for such a studied system is especially important, as well as the careful choice of a reference scenarios for comparison.

\subsubsection{Overview of the BIORARE process}

The BIORARE process relies on a new technology: microbial electrosynthesis. This is based on the principle of stimulating microbial activity in an electrolytic cell in order to catalyse microbial reduction of organic molecules leading to the synthesis of useful products. The consequence is the direct production of bio-based chemicals from organic waste.

A BES concept is based on an electrolytic cell set up with two distinct compartments separated by a membrane: (see Fig.1). Each compartment includes a bio-electrode made of covered by a biofilm. In the bio-cathode compartment, a carbon source, (carbon dioxide in this case), is needed while a carbon-rich input has to be provided to the anodic compartment. As shown in Fig. 1, each of the individual unit steps making up the system requires inputs and generates outputs. Because some outputs can become inputs for other process steps, a synergistic approach is appropriate and described here. The first step, hydrolysis, is a catabolic process in which bacteria breaks down (by hydrolysis) complex organic molecules into simpler ones such as carboxylic acid, organic fatty acids, hydrogen gas and carbon dioxide (McCarty, 1964). This pre-treatment step (preceded by sanitisation at $70{ }^{\circ} \mathrm{C}$ (Smith, 2015)) leads to the production of $\mathrm{CO}_{2}$, (resulting from organic matter degradation), and, a liquid waste stream which is enriched in volatile fatty acids (VFAs) such as acetate, propionate and butyrate. The pre-treated effluent is then passed through a screw press producing a liquid stream that contains most of the VFAs and a concentrate. The liquid stream rich in VFA is then injected in the anodic compartment and the concentrate is sent to the digestion unit in order to produce a biogas comprising $60 \mathrm{v} . \%$ of methane $\left(\mathrm{CH}_{4}\right)$ and $40 \mathrm{v} . \%$ of $\mathrm{CO}_{2}$.

Within the anodic compartment of the BES, the stimulated microorganisms breakdown the VFAs (eq. 13) with the extracted electrons flowing to the bio-cathode (Lovley, 2006; Moscoviz et al., 2017);

$$
\begin{aligned}
& \text { Acetate }+2 \mathrm{H}_{2} \mathrm{O} \rightarrow 2 \mathrm{CO}_{2}+7 \mathrm{H}^{+}+8 \mathrm{e}^{-} \\
& \text {Propionate }+4 \mathrm{H}_{2} \mathrm{O} \rightarrow 3 \mathrm{CO}_{2}+13 \mathrm{H}^{+}+14 \mathrm{e}^{-} \\
& \text {Butyrate }+6 \mathrm{H}_{2} \mathrm{O} \rightarrow 4 \mathrm{CO}_{2}+19 \mathrm{H}^{+}+20 \mathrm{e}^{-}
\end{aligned}
$$

The $\mathrm{CO}_{2}$ produced from the previous hydrolysis step can be directly injected into the cathodic compartment of the BES unit in which the biomolecules are produced. A BES cell can produce a range of organic molecules depending on the reduction reactions taking place at the bio-cathode. Since the reduction reactions depend on electrical potentials, specific biomolecules can be targeted. The production of succinic acid follows the eq.4-1 and eq.4-2 at the bio-cathode:

$$
\begin{aligned}
& 2 \mathrm{CO}_{2}+7 \mathrm{H}^{+}+8 \mathrm{e}^{-} \rightarrow \text { Acetate }+2 \mathrm{H}_{2} \mathrm{O} \\
& 2 \mathrm{CO}_{2}+\text { Acetate }+7 \mathrm{H}^{+}+6 \mathrm{e}^{-} \rightarrow \text { Succinic acid }+2 \mathrm{H}_{2} \mathrm{O}
\end{aligned}
$$


Moreover, the BES unit generates a VFAs-depleted effluent but which still constitutes a carbon-rich resource useful for the production of biogas from the AD process. Electricity and heat for the process comes from the cogeneration unit fuelled by the biogas produced.

Fig. 1. Simplified representation of the BIORARE process studied

\subsubsection{Proposal of a LCA-based methodology}

The BIORARE process comprises three main parts as illustrated by Fig. 1. Between these parts, there are interactions and dependencies of note because downstream flows production depends on the operating conditions of the upstream flows production and vice versa. The technical aspect of these dependencies is explained in the following section (2.2.).

The common LCA methodology is based on four main steps widely applied respecting ISO standards and recommended guidelines (2006a, 2006b, European Commission, 2010). The first step is the definition of the goal and scope, followed by the inventory, the impact assessment and the interpretation, as shown in Fig. 2. The compilation of the inputs and the outputs of a simple system, meaning no existing interactions between flows, can be performed by using this methodology as it is. However, it is necessary to adjust the methodology for complex and low-TRL systems, such as the BIORARE process. The very design of the BES is the subject of current research and there are thus currently no industrial existing processes to confirm the selected values nor the strength of the flow dependencies. In order to design the BIORARE process, the sensitive parameters and dependencies should be identified and analysed. As shown in Fig. 2, the functional unit is constrained by the inventory step due to the streams dependencies. For this reason, we propose an adjusted LCA methodology which synchronizes the first and the second step of the standard methodology (Fig. 2). At last, the interpretation step comprises the study of the production efficiency within environmental and economic aspects, in other words the eco-efficiency of the BIORARE process. The eco-efficiency aims to identify the targeted biomolecules presenting the best environmental interest which is a trade-off between environmental performances of the BIORARE process and the potential market share of targeted molecules (see section 2.2.4.)

Fig. 2. Adjusted LCA methodology for the BIORARE process

\subsection{LCA-based methodology applied to the BIORARE process}

\subsubsection{The goal, scope and boundaries of the study}

The goal of this study is to identify the sensitive parameters that specify the BIORARE process and their influence on the subsequent environmental impact of its application. Fig. 3 illustrates the interdependency of the AD system and the BES system. In most LCA studies based on waste reuse, no burden is allocated to the waste input and thus it is excluded from the boundary of the BIORARE system as well. The raw materials used for the electrodes and the membrane, as well as any other chemicals used in the BIORARE system, are included in the system boundary. On the other hand, fabrication material (for example: hydrolysis and $\mathrm{AD}$ digestion tanks, BES reactor except for the electrodes and the membrane) are all omitted due to their long lifetime.

The functional unit (FU), which quantifies the primary purpose of the BIORARE technology and which allows for a comparative assessment, is defined as the production of 1,000 tonnes of the targeted product (succinic acid) by treating the corresponding amount of organic waste. The latter has been determined to be up to 35,000 tonnes for the production of 1,000 tonnes of succinic acid.

The design specification of the BES unit remains an objective of the BIORARE project. The linking up of such a unit with an anaerobic digestion plant has not yet been done, neither theoretically nor in practice. A relevant and consistent model for the BES unit and its implementation in conjunction with an anaerobic 
digestion plant are central issues covered by this paper: its application will also address the sensitivity analyses already discussed.

Fig. 3. System boundaries for the LCA analysis of the BIORARE system

\subsubsection{Inventory}

The life cycle scenarios presented here all were modelled using the GaBi 7.2.1 LCA software package (Thinkstep, 2016). The foreground life cycle inventory (LCI) data were compiled from experimental tests, detailed documents and previous work from each of the author's respective institutions ("Biorare project," 2018). Special attention was given to the inventory of the anaerobic digestion process, that it respected existing guidelines on biowaste management (Manfredi et al., 2011). The background life cycle inventory data (e.g. with respect to electricity, heat, graphite, steel, cationic membrane, and all chemicals cited) is provided by the ecoinvent database (Wernet et al., 2016) and the PE international (former name of Thinkstep) database ("GaBi Databases: GaBi Software," n.d.). Even with good data, the scaling up BIORARE technology depends upon appropriate calculations. To perform this LCA, the behaviour of the BES has to be understood, as well as its ability to produce succinic acid and the necessary operating parameters. Since no BES coupled with anaerobic digestion currently exists at even the pilot scale, an innovative calculation methodology is proposed here. In the following section the inventories of the BES unit and the anaerobic digestion system are described.

\subsubsection{Stream constraints}

An important characteristic that quantities the strength of organic wastes is its capacity to consume oxygen. This value can be determined in different ways but most relevantly in this case by the Chemical Oxygen Demand (COD) property. The quantity of succinic acid produced depends on the capacity of the BES to process COD taking into account the cathodic coulombic efficiency ( $C E_{\text {cathode }}$ ) and the current density $(\mathrm{J})$, as summarized by equation 5 :

$m_{\text {succinic acid }}=\frac{J \times C E_{\text {cathode }}}{m_{C O D / \text { succinicacid }} \times f_{Q_{C O D}}}$

where $m_{C O D / \text { succinic acid }}$ is the quantity of COD to produce one unit mass of succinic acid and $f_{Q_{C O D}}$ is the quantity of electric charge the BES requires to breakdown a unit mass of COD (expressed in A.day $/ \mathrm{g}_{\mathrm{COD}}$.). The volume of the BES depends on the output quantity of the product, thereby setting the required surface area of the electrode $\left(S_{\text {electrodes }}\right)$ :

$S_{\text {electrodes }}=2 \times \frac{m_{\text {succinic acid }} \times F \times x_{e-}}{t \times J \times C E_{\text {cathode }} \times M_{\text {succinic acid }}}$

where $m_{\text {succinic acid }}$ is the quantity of succinic acid produced, $F$ is the Faraday constant, $x_{e-}$ the number of electrons required at the cathode, $t$ the time expressed in seconds and $M_{\text {succinic acid }}$ the molar mass of the molecule of succinic acid. It is expected that the size of the BES unit increases with the production rate resulting in an increased total energy demand. One of the consequences is that the biogas combustion might not then produce enough energy to supply the BES unit and the AD system. It is further assumed that another consequence is the increase of the $\mathrm{CO}_{2}$ and VFAs demand of the BES unit. The production rate of the succinic acid thus depends on the quality of the organic waste and also on the electrochemical parameters and the BES framework design.

The amount of energy produced from biogas is constrained by the substrate input to the AD digestion unit. Clearly, the methanogenic bacteria generate more biogas when they receive more substrate. The substrate is provided to the digestion unit by two other units: the BES unit and the separation unit (Fig. 1). This substrate composition depends on the performance of the hydrolysis step which hydrolyses the organic matter in the incoming sanitised waste. The efficiency of the hydrolysis phase is subject to various parameters such as raw waste composition, inoculums, $\mathrm{pH}$ and temperature (He et al., 2012). This 
efficiency is expressed as the hydrolysis yield which corresponds to the COD fraction of the total biodegradable COD of waste that is effectively solubilised. The quantity of waste required by the BIORARE process will be high when the hydrolysis yield is low, in order to meet the VFAs demand of the BES unit. However, as a consequence, the substrate loading of the AD tank then increases leading to an increased yield of biogas.

Since each step of the process influences each other via several conflicting relationships between the various stages of the process, it is difficult to anticipate the environmental outcomes as a result of the variation of a single parameter. LCA is thus the most appropriate approach to estimate those global outcomes by taking into account of all the streams involved and to set out their respective dependencies.

\subsubsection{Inventory of the BES process}

The electrochemical performances of the BES drive the calculation methodology. The required VFA $\left(m_{V F A}\right)$ and $\mathrm{CO}_{2}\left(m_{\mathrm{CO}_{2} i}\right)$ inputs depends on the criteria set out in Table 1 and are calculated according to equations 7 and 8 , respectively, where $m_{C O D}$ and $D M$ is respectively the COD value and the dry matter content of the hydrolysed waste handled annually by the BES unit, $C_{C O D}$ is the COD value of the VFA content, $m_{\mathrm{CO}_{2} / \mathrm{COD}_{\text {acetate }}}$ is the amount of $\mathrm{CO}_{2}$ equivalent to one gram of $\mathrm{COD}$ from acetate decomposition and $m_{C O D_{\text {acetate }}}$ is the COD value of acetate.

$$
\begin{array}{ll}
m_{V F A}=m_{C O D} \times D M / C_{C O D} & \text { eq. } 7 \\
m_{C O_{2} i}=m_{C O_{2} / C O D_{\text {acetate }}} \times m_{V F A} \times m_{C O D_{\text {acetate }}} & \text { eq. } 8
\end{array}
$$

\begin{tabular}{|c|c|c|c|}
\hline Parameter & Origin of data & Quantity & Unit \\
\hline Current density $(J)$ & Experimental tests & 20 & A.m ${ }^{2}$ \\
\hline Faradaic yield $(F Y)$ & Experimental tests & 65 & $\%$ \\
\hline $\begin{array}{l}\text { Electronic charge borne by one gram } \\
\text { of } \operatorname{COD}\left(Q_{C O D}\right)\end{array}$ & $Q_{e^{-}} \times n_{e^{-} / n_{C O D}} / M_{O_{2}}$ & 0.14 & A.day.g $\mathrm{g}^{-1} \mathrm{COD}$ \\
\hline COD supply $\left(m_{C O D}\right)$ & $365 \times J /\left(Q_{C O D} \times F Y\right)$ & 4.02 & kt.yr ${ }^{-1}$ \\
\hline $\begin{array}{l}\text { Dry matter content of the hydrolysed } \\
\text { waste }(D M)\end{array}$ & Experimental tests & 0.25 & $\mathrm{~kg} . \mathrm{l}^{-1}$ hydro. waste \\
\hline $\begin{array}{l}\text { Total COD in the hydrolysed waste } \\
\left(C_{C O D}\right)\end{array}$ & Experimental tests & 22.6 & g. $1^{-1}$ hydro. waste \\
\hline $\begin{array}{l}\text { COD of acetate in the hydrolysed } \\
\text { waste }\left(m_{C O D_{\text {acetate }}}\right)\end{array}$ & Experimental tests & 13.1 & g. $1^{-1}$ hydro. waste \\
\hline
\end{tabular}

Table 1. Data used for the inventory of the BES process

(1) $Q_{e^{-}}$is the charge borne by one mole of electrons, $n_{e^{-} / n_{C O D}}$ is the number of moles of electrons for one mole of COD, and, $M_{O_{2}}$ is the molar mass of oxygen.

\subsubsection{Inventory of the anaerobic digestion process}

All of the streams are specified using the waste characteristics set out in Table 2. Knowing the dry matter content of the substrate, methane production $\left(\mathrm{m}_{\mathrm{CH} 4}\right)$ from digestion can be estimated by applying the formula (eq. 9):

$m_{C H 4}=V_{C H_{4} / V M} \times B M P \times r_{V M / D M} \times \rho_{C H_{4}} \times D M \quad$ eq. 9

Where $\mathrm{V}_{\mathrm{CH} 4 / \mathrm{VM}}$ is the volume of methane produced per kilogram of volatile matter (VM) and is assumed to be at 450 liters/kg; BMP is the methanogenic potential of the substrate and is assumed to be at $91 \%$; $\mathrm{r}_{\mathrm{VM} / \mathrm{DM}}$ is the ratio between volatile matter and dry matter; $\rho_{\mathrm{CH} 4}$ is the volumetric mass density of methane; and $D M$ is the dry matter mass of the substrate.

From the methane production, carbon dioxide production can be estimated knowing their volume ratio (60 v. $\% \mathrm{CH}_{4}, 40$ v.\% $\mathrm{CO}_{2}$ ). Gas leaks are also taken into account and are assumed to be 5 wt. $\%$. The 
biogas is fed to a cogeneration unit, which produces heat and electricity that goes to meet some of the input required of the BIORARE process. For the rest of electricity and heat demand, system expansion rule of the boundaries is used for their recovery (ISO, 2006b). Additional electricity and heat come from the French power grid and from the production of steam from natural gas.

Table 2. Data used for the inventory of anaerobic digestion

\begin{tabular}{llcc}
\hline Parameter & Origin of data & Quantity & Unit \\
\hline Dry matter content of waste & Experimental tests & 25.0 & $\%$ \\
\hline Hydrolysis yield & Experimental tests & 19.7 & \\
\hline Volume content of $\mathbf{C O}_{2}$ in the hydrolysis gas & $\begin{array}{l}\text { Experimental tests and experts } \\
\text { opinion }\end{array}$ & 80.0 & $\%$ \\
\hline Volume content of $\mathbf{H}_{2}$ in the hydrolysis gas & $\begin{array}{l}\text { Experimental tests and experts } \\
\text { opinion }\end{array}$ & 20.0 & $\%$ \\
\hline Gas leak & $\begin{array}{l}\text { Experimental tests and experts } \\
\text { opinion }\end{array}$ & 5.0 & $\%$ \\
\hline Volatile matter and dry matter ratio & $\begin{array}{l}\text { Experimental tests and experts } \\
\text { opinion }\end{array}$ & 85.0 & $\%$ \\
\hline $\begin{array}{l}\text { Volume of } \mathbf{C O}_{2} \text { produced for one kilogram of } \\
\text { volatile matter input }\end{array}$ & $\begin{array}{l}\text { Experimental tests and experts } \\
\text { opinion }\end{array}$ & 25.0 & 1 \\
\hline
\end{tabular}

This methodology applied follows the "bottom-up" approach (Silveira et al., 2017; Swan and Ugursal, 2009), which focuses on the sub-systems (here the BES performance) to arrive at the whole system (here the production of succinic acid and carbon dioxide). This approach is appropriate for LCA studies on bioelectrochemical systems because it is essentially based on the COD measurement. In most cases dealing with biowaste sludge, this parameter is the dominant factor which is widely used to characterise the waste streams.

\subsubsection{Sensitivity analysis}

This subsection presents parameters of the BIORARE technology which could influence the environmental impacts of the complete process including the AD step. In the following sections, current density, hydrolysis yield and management of the $\mathrm{CO}_{2}$ stream are discussed as possible sensitive parameters.

\section{Current density}

The BES design has to satisfy various conditions to ensure its productivity. Some parameters are fixed such as electrode component and membrane thickness. To optimize the BES, its electrochemical performance has to be considered. The current density $(\mathrm{J})$ greatly influences the efficiency of a BES unit. Laboratory scale experiments have been performed and revealed that the BES can produce succinic acid at different current densities. The lowest operational value is $5 \mathrm{~A} \cdot \mathrm{m}^{-2}$ and the highest $300 \mathrm{~A} \cdot \mathrm{m}^{-2}$. In between, current densities of $20 \mathrm{~A} . \mathrm{m}^{-2}$ and $100 \mathrm{~A} \cdot \mathrm{m}^{-2}$ were used in this study. The set of scenarios are thus labelled J5, J20, J100 and J300, corresponding to the current density. As a consequence of varying the current density, the electrical potential difference $(\Delta \mathrm{V})$ between the two electrodes also changes as illustrated by equation 10 :

$\Delta V=V_{\text {bio-anode }}-V_{\text {bio-cathode }}+J \times R \quad$ eq. 10

where $R$ is the electrolyte resistance, $V_{\text {bio-anode }}$ is the electrical potential at the anode, and, $V_{\text {bio-cathode }}$ is the electrical potential at the cathode. The electrical potential difference is a key variable because the electrical charge input of the BES is determined by it. Indeed this input is the result of the product of the electrical potential difference, the current density, the electrode surface area and the production time. 
By varying the current density, the quantity of succinic acid produced varies also. Indeed, the amount produced generally increases with the current density. As a consequence, the surface area of the electrodes has to be adjusted in order to produce the same amount of succinic acid for all current density values tested, which is necessary in the interest of the comparative LCA. In Table 3 the adjusted electrode surface, mass and energy demand are presented for the 4 scenarios studied.

Table 3. Influence of current density $(\mathrm{J})$ variation on BES inputs

\begin{tabular}{llllll}
\hline Scenario & $\mathbf{J}\left(\mathbf{A} \cdot \mathbf{m}^{-2}\right)$ & $\boldsymbol{\Delta} \mathbf{V}(\mathbf{V})$ & $\mathbf{S}_{\text {BES }}\left(\mathbf{m}^{2}\right)^{(\mathbf{1})}$ & $\mathbf{m}_{\text {elec }}(\mathbf{k g})^{(2)}$ & $\mathbf{E}(\mathbf{J})^{(3)}$ \\
\hline $\mathbf{J 5}$ & 5 & 0.88 & $8.54 \times 10^{4}$ & $1.54 \times 10^{4}$ & $1.19 \times 10^{13}$ \\
$\mathbf{J 2 0}$ & 20 & 1.14 & $2.14 \times 10^{4}$ & $3.84 \times 10^{3}$ & $1.54 \times 10^{13}$ \\
$\mathbf{J 1 0 0}$ & 100 & 2.5 & $4.27 \times 10^{3}$ & $7.69 \times 10^{2}$ & $3.37 \times 10^{13}$ \\
$\mathbf{J 3 0 0}$ & 300 & 5.90 & $1.42 \times 10^{3}$ & $2.56 \times 10^{2}$ & $7.95 \times 10^{13}$ \\
\hline
\end{tabular}

(1) surface area of electrode; (2) mass of electrode; (3) electricity input of the BES

\section{Hydrolysis yield}

The principle step of pre-treatment is the hydrolysis of the organic matter of the sanitised waste stream. This process encourages the solubilisation of the COD content to produce VFAs which can then be used in the BES unit at the bio-anode. The biochemical methane potential (BMP) assay is a common analytical method used to estimate the biodegradability of organic substrates under anaerobic conditions. The degradable COD can be calculated from the observed specific methane yield and the theoretical $350 \mathrm{ml}$ of methane (at STP) per gram of COD stabilized (McCarty, 1964). In the context of this study, BMP assays were conducted on biowaste and resulted in a degradable COD of $3.2 \mathrm{~g}_{\mathrm{COD}} / \mathrm{g}_{\mathrm{DM}}$. Not all the degradable COD can be broken down by hydrolysis. Hydrolysis yield represents the dissolved COD over the initial degradable COD in the biowaste. The biowaste used in the BIORARE project had a dry matter content of $25 \% \mathrm{w} / \mathrm{w}$. Theoretical hydrolysis yields of $10 \%$ (scenario Y10), $20 \%$ (scenario Y20), $50 \%$ (scenario Y50) and $80 \%$ (scenario Y80) were considered. This has a very strong influence on the VFAs content of the hydrolysed waste sent to the BES unit. As shown in Table 4, this increases with the hydrolysis yield thus changing the amount of waste needed downstream. The total amount of $\mathrm{CO}_{2}$ produced from the hydrolysis stage decreases if the hydrolysis yield increases because the required amount of organic waste feed then decreases On the other hand, a poor $10 \%$ yield would require eight times more waste than in the case of a $80 \%$ yield, resulting in eight times more $\mathrm{CO}_{2}$ available for the BES biocathode. When the $\mathrm{CO}_{2}$ produced from the hydrolysis stage is not enough to meet the demand of the biocathode, $\mathrm{CO}_{2}$ produced at the bioanode (see eq.1, eq.2 and eq.3) is diverted to the biocathode.

Table 4. Analysis of the hydrolysed waste (and $\mathrm{CO}_{2}$ production) as a function of the hydrolysis yield

\begin{tabular}{|c|c|c|c|c|c|c|}
\hline Scenario & $\begin{array}{l}\text { Hydrolysis } \\
\text { yield }\end{array}$ & $\begin{array}{l}\text { COD of the } \\
\text { hydrolysed } \\
\text { waste } \\
\left(\text { g. } .^{-1}\right)\end{array}$ & $\begin{array}{l}\text { Organic } \\
\text { waste } \\
\text { required } \\
\text { (kg) }\end{array}$ & $\begin{array}{c}\text { Required } \mathrm{CO}_{2} \\
\text { input of the } \\
\text { BES (at the } \\
\text { bio-cathode) } \\
\text { (kg) }\end{array}$ & $\begin{array}{c}\mathrm{CO}_{2} \\
\text { production } \\
\text { from } \\
\text { hydrolysis } \\
(\mathrm{kg}) \\
\end{array}$ & $\begin{array}{l}\text { Additional } \\
\mathrm{CO}_{2} \text { to } \\
\text { send to the } \\
\text { biocathode }\end{array}$ \\
\hline Y10 & $10 \%$ & 28 & $6.83 \times 10^{7}$ & \multirow{4}{*}{$3.05 \times 10^{5}$} & $5.43 \times 10^{5}$ & - \\
\hline Y20 & $20 \%$ & 56 & $3.41 \times 10^{7}$ & & $2.71 \times 10^{5}$ & $\begin{array}{c}\text { From BES } \\
\text { bioanode }\end{array}$ \\
\hline Y50 & $50 \%$ & 141 & $1.37 \times 10^{7}$ & & $1.09 \times 10^{5}$ & $\begin{array}{c}\text { From BES } \\
\text { bioanode }\end{array}$ \\
\hline Y80 & $80 \%$ & 226 & $8.54 \times 10^{6}$ & & $6.78 \times 10^{4}$ & $\begin{array}{c}\text { From BES } \\
\text { bioanode }\end{array}$ \\
\hline
\end{tabular}


Reducing and/or recovering $\mathrm{CO}_{2}$ emissions from industrial processes is a large part of environmental policy (Bygrave and Ellis, 2003; Jos et al., 2016). $\mathrm{CO}_{2}$ emissions arise in the application of BIORARE technology: from hydrolysis, electrolysis (BES) and cogeneration (Table 5). The values correspond to the scenarios Y20 and $\mathrm{J} 20$.

Table 5. Summary of carbon dioxide emissions

\begin{tabular}{|c|c|c|c|c|}
\hline \multirow{2}{*}{ Unit process } & \multirow{2}{*}{$\begin{array}{l}\text { Purpose of the } \\
\text { unit }\end{array}$} & \multirow{2}{*}{$\begin{array}{l}\mathrm{CO}_{2} \text { production } \\
\text { mechanism }\end{array}$} & \multicolumn{2}{|c|}{ Succinic acid production $(1,000 \mathrm{t})$} \\
\hline & & & $\begin{array}{c}\text { Quantity of } \mathrm{CO}_{2} \text { produced } \\
(\mathrm{kg})\end{array}$ & $\begin{array}{c}\text { Quantity of } \mathrm{CO}_{2} \text { required as input } \\
(\mathrm{kg})\end{array}$ \\
\hline $\begin{array}{l}\text { Hydrolysis } \\
\text { Unit }\end{array}$ & $\begin{array}{l}\text { Pre-treatment of } \\
\text { waste }\end{array}$ & $\begin{array}{l}\text { Hydrolysis of } \\
\text { waste }\end{array}$ & $2.76 \times 10^{5}$ & \\
\hline BES Unit & $\begin{array}{l}\text { Functional } \\
\text { biomolecules } \\
\text { production }\end{array}$ & $\begin{array}{l}\text { Breakdown of } \\
\text { VFA at anode }\end{array}$ & $6.73 \times 10^{5}$ & $3.06 \times 10^{5}$ \\
\hline AD Unit & $\begin{array}{c}\text { Anaerobic } \\
\text { biotransformation } \\
\text { of substrate }\end{array}$ & $\begin{array}{l}\text { Biogas } \\
\text { production (no } \\
\text { losses) }\end{array}$ & $2.16 \times 10^{6}$ & - \\
\hline Cogeneration & $\begin{array}{c}\text { Biogas recovered } \\
\text { into heat and } \\
\text { electricity }\end{array}$ & $\begin{array}{l}\text { From methane } \\
\text { combustion }\end{array}$ & $5.22 \times 10^{6}$ & - \\
\hline
\end{tabular}

The hydrolysis unit emits $\mathrm{CO}_{2}$ via the mechanism of organic matter degradation, which can also be responsible for $\mathrm{H}_{2}$ emission. The quantity of $\mathrm{CO}_{2}$ is directly estimated from the volatile and dry matter content of waste. Thus $\mathrm{CO}_{2}$ emission from hydrolysis is determined by the nature and composition of the organic waste used. Among the four unit processes (Table 5), the hydrolysis unit and the BES unit generate the smallest amounts of $\mathrm{CO}_{2}$. The cogeneration unit and the digestion unit are responsible for, respectively, $63 \%$ and $26 \%$ of the total production of $\mathrm{CO}_{2}$ from the BIORARE process. The cogeneration is the biggest source of $\mathrm{CO}_{2}$ because of $\mathrm{CO}_{2}$ from biogas and supplementary $\mathrm{CO}_{2}$ production due to methane combustion reaction. The BES unit is the only part of the process that also requires $\mathrm{CO}_{2}$ as input. The objective to recover $\mathrm{CO}_{2}$ emissions could be achieved by means of streams management strategies that are presented below. Sending all of the $\mathrm{CO}_{2}$ streams into the BES bio-cathode would not increase the amount of succinic acid produced because of the limiting effect of VFAs on biomolecule production. Three different management scenarios for the input of $\mathrm{CO}_{2}$ into the BES unit are studied are presented in Fig. 4:

Fig. 4. $\mathrm{CO}_{2}$ streams management scenarios (A, B and $\left.\mathrm{C}\right)$

- Management A: the $\mathrm{CO}_{2}$ comes mostly from hydrolysis. 276 tonnes of $\mathrm{CO}_{2}$ from hydrolysis are sent to the BES unit for the production of succinic acid. The hydrolysis process does not produce enough $\mathrm{CO}_{2}$ to cover the BES unit input. Therefore, some of the $\mathrm{CO}_{2}$ produced in the cathodic compartment (approximately $10 \%$ of the $\mathrm{BES} \mathrm{CO}_{2}$ demand) of the $\mathrm{BES}$ unit is recycled to the anodic compartment. The rest of the anodic $\mathrm{CO}_{2}$ is sent to the purification unit.

- Management B: $\mathrm{CO}_{2}$ is provided by the biogas stream. The biogas output of the digestion unit is directly sent to the BES unit. The bacteria in the BES unit removes from the biogas the required amount of $\mathrm{CO}_{2}$, thus allowing the subsequent injection of a methane enriched biogas (composed of 37 v.\% $\mathrm{CO}_{2}$ and 63 v.\% $\mathrm{CH}_{4}$ ) into the cogeneration unit. This hypothesis has yet to be verified. All the $\mathrm{CO}_{2}$ from the bio-anode and all that from the hydrolysis unit are sent to the purification unit.

- Management $\mathrm{C}$ : the BES unit is not balanced in terms of $\mathrm{CO}_{2}$ input/output. The anodic compartment produces more $\mathrm{CO}_{2}$ than the cathodic compartment requires. Around $45 \%$ of the 

the purification unit.

Once purified, $\mathrm{CO}_{2}$ might be used as a feedstock in the food industry, pharmaceuticals or analytical chemistry. Several purification techniques can be applied for $\mathrm{CO}_{2}$ recovery and purification. Of these techniques, pressure swing adsorption (PSA) appeared to be the most suited to BIORARE technology (Overcash et al., 2007; Thambimuthu et al., 2002). This process operates on a repeated cycle with the basic steps being adsorption of $\mathrm{CO}_{2}$ on adsorbent beds and then regeneration through pressure reduction. $\mathrm{CO}_{2}$ recovery efficiency relies on many factors such as the initial purity of the $\mathrm{CO}_{2}$ stream. In the case of BIORARE technology, the $\mathrm{CO}_{2}$ streams arising from the hydrolysis unit, the BES unit, the AD digestion unit and cogeneration make up $80 \mathrm{v} . \%, 40 \mathrm{v} . \%, 40 \mathrm{v} . \%$ and $11 \mathrm{v} . \%$, respectively. To limit the potential environmental impacts of the $\mathrm{CO}_{2}$ purification unit, only that $\mathrm{CO}_{2}$ produced by the hydrolysis and BES units is recovered.

When $\mathrm{CO}_{2}$ is recovered, the BIORARE process becomes a dual-output system that is the production of both succinic acid and $\mathrm{CO}_{2}$. In such a case, it is appropriate to partition the related environmental burdens (ISO, 2006b). In LCA, this approach is called allocation. The inputs and outputs of a system can be partitioned between the different products on the basis of their underlying physical relationships, for example their mass ratio or their energy content ratio. In the case of BIORARE technology, the physical relationship between the succinic acid and $\mathrm{CO}_{2}$ cannot be directed to favour the production of one product over the other. In this specific case, the allocation can be performed in proportion to the economic value of each product (Ardente and Cellura, 2012). The allocation methodology and inventory collection of the purification system are described in the annexe, "Supporting Material".

\subsubsection{Environmental impact assessment}

A procedure is required to calculate the potential environmental impact of each described scenario. This is the link between the released (or consumed) substance and its potential environmental impact. The January 2016 revision of the CML-IA method is used in this study (Heijungs, R. et al., 2001). There are ten impact categories listed that determine potential impact transfers. The categories are: abiotic depletion, acidification, eutrophication, global warming, ozone depletion, photochemical ozone creation, human toxicity and ecotoxicity categories (freshwater, marine and terrestrial). The scenarios to be tested against these impacts (described above) are summarised in Table 6.

Table 6. Summary of scenarios evaluated

\begin{tabular}{|c|c|c|c|c|}
\hline Parameter & Scenario label & Tested values or description & Methodology & Results \\
\hline \multirow{4}{*}{$\begin{array}{c}\text { Current density of the } \\
\text { BES }\end{array}$} & J5 & 5 A.m ${ }^{-2}$ & \multirow{4}{*}{$\begin{array}{l}\text { Section } \\
2.4 .2 .1\end{array}$} & \multirow{4}{*}{$\begin{array}{c}\text { Section } \\
3.1 .\end{array}$} \\
\hline & J20 & 20 A.m ${ }^{-2}$ & & \\
\hline & J100 & 100 A.m ${ }^{-2}$ & & \\
\hline & $\mathbf{J 3 0 0}$ & 300 A.m ${ }^{-2}$ & & \\
\hline \multirow{4}{*}{$\begin{array}{l}\text { Hydrolysis yield of the } \\
\text { fermentation step }\end{array}$} & Y10 & $10 \%$ & \multirow{4}{*}{$\begin{array}{l}\text { Section } \\
\text { 2.4.2.2. }\end{array}$} & \multirow{4}{*}{$\begin{array}{c}\text { Section } \\
3.2 .\end{array}$} \\
\hline & Y20 & $20 \%$ & & \\
\hline & Y50 & $50 \%$ & & \\
\hline & Y80 & $80 \%$ & & \\
\hline \multirow{3}{*}{$\begin{array}{l}\mathrm{CO}_{2} \text { emission and } \\
\text { reuse management }\end{array}$} & $\mathbf{A}$ & $\mathrm{BES} \mathrm{CO}_{2}$ partial feeding from fermentation unit & \multirow{3}{*}{$\begin{array}{l}\text { Section } \\
2.4 .2 .3\end{array}$} & \multirow{3}{*}{$\begin{array}{l}\text { Section } \\
3.3 \text {. }\end{array}$} \\
\hline & $\mathbf{B}$ & $\mathrm{BES} \mathrm{CO}_{2}$ feeding from digestion unit & & \\
\hline & $\mathbf{C}$ & $\mathrm{BES} \mathrm{CO}_{2}$ partial auto-feeding & & \\
\hline
\end{tabular}

\subsubsection{Eco-efficiency of biosuccinic acid production}

When talking about eco-efficiency, the World Business Council For Sustainable Development (WBCSD) refers to a philosophy based on creating more goods and services with ever less use of resources, waste and pollution (Helminen, 2000). By applying the eco-efficiency criterion, it is possible to compare two processes, which have the same purpose but operate in different ways, taking into account the environmental point of view but bound to an economic aspect. In the BIORARE project, several chemical 
products can be produced as explained in section 2.1. Targeting a different product to succinic acid would result in treating a different amount of biowaste because the cathodic reaction is unlikely to be the same. The eco-efficiency criterion can be represented by the equation 11 (Kuosmanen and Kortelainen, 2005):

$$
E E=\frac{\text { Economic value added }}{\text { Environmental damage }} \quad \text { eq. } 11
$$

This measurement requires that the economic value added should be known or could be calculated from available data. However, the BIORARE process is at an early stage of development and data on investment, production cost as well as product sale price is unavailable. The eco-efficiency criterion is thus revised as follows (eq. 12):

$$
E E=\frac{\% \text { market share }}{\Delta I} \quad \text { eq. } 12
$$

The market share that the BIORARE process might claim is based on the current French and European market shares of biosuccinic acid. $\Delta I$ is the difference between the impact value of the BIORARE scenario and that of a reference scenario, divided by the sum of the impact values of both scenarios. The reference scenario of BIORARE succinic acid has been discussed separately (see the section, Supporting Material). $\Delta I$ can range from -1 to 1 . A negative value indicates environmental burdens whereas a positive value means environmental benefits with respect to the reference scenario. Conversely, a positive value shows that the technology is environmentally better than the reference scenario. Data on the environmental benefit/burdens and the reference scenario are given separately in the section, "Supporting Material".

The production of succinic acid through the BIORARE technology can be assimilated to an environmental biorefinery. Depending on the electrochemical conditions of the BES, several biomolecules can be produced (Rabaey and Rozendal, 2010). Because the stock of organic is deterministic (Gargalo et al., 2017) and would be moderate for mass production, it is necessary to identify the production of the biomolecule which is part of the proper market along with good environmental performances. In order to go towards the proper market, the production of succinic acid is compared to the production of bioethanol because the latter is part of an important energy market whereas succinic acid is considered an intermediate commodity. Indeed, the French and European markets for succinic acid are still in their infancy. As the study takes place in France, it is necessary to first evaluate the potential volumes of biowaste in France that could be treated by AD. In metropolitan France, nine existing AD units were identified. By adding up their operating capacities, approximately 701,000 tonnes of biowaste could be treated annually ("SINOE® déchets," n.d.). If a BIORARE process is to be implemented at each French AD site, 9,000 tonnes of bioethanol or 20,000 tonnes of succinic acid could be produced annually. Considering theses production rates, succinic acid produced using the BIORARE technology would represent $87 \%$ of the French market and $46 \%$ of the European market ("Chemical industry awaits for bio-succinic acid potential," n.d.; Cok et al., 2014; Weastra, 2012), whereas the production of bioethanol would only represent $0.98 \%$ of the French market and just $0.27 \%$ of the European market (Flach et al., 2016).

\section{Results and discussion}

In this section, the results of the sensitivity analysis are presented. Firstly, the importance of the parameters describing the BES process is discussed in order to show their effect on performance. Section 3.2. deals with the constraints on the AD digestion brought about by the preceding hydrolysis step which influences all the waste-related streams in the BIORARE system. For instance, the quantity of greenhouse gases emitted during $\mathrm{AD}$ digestion and subsequent cogeneration, especially $\mathrm{CO}_{2}$, varies with the quantity of input substrate in the feed stream. In order to limit such emissions, $\mathrm{CO}_{2}$ management strategies in the 
context of LCA are presented in section 3.3. The outcome of alR life cycle impact assessment (LCIA) is discussed in a final discussion.

\subsection{The effect of current density in the BES on the environmental impact of the process}

Changing the current density results in resizing the BES unit in terms of the electrode surface area in order to produce the same quantity of product. The quantity of electrode material increases with surface area. By contrast, the electricity consumed by the BES unit increases when the electrode surface decreases. This is due to the fact that a higher current density implies a higher voltage and thus a higher energy demand.

Thus increasing the BES unit production efficiency results in a trade-off between the need of electrode material and the electricity consumption. Through a comparative LCA, the consequences of this trade-off on potential environmental impacts are investigated, with the main results shown in Fig. 5. Electrode material is the highest contributing fraction of the BIORARE technology in the J5 scenario when considering the process contribution to acidification, eutrophication, climate change, ecotoxicity categories and photochemical oxidation. The contribution of the electrodes decreases as the current density increases, as shown also by Table 3. Meanwhile the electricity cost contribution increases given that the BES requires more and more energy to work at higher current densities. The environmental burdens of electricity production (based on the sources used to power the French grid) seem to be more significant than the burdens of the electrodes production since the scenario J300 is the least beneficial scenario.

Fig. 5. Comparative analysis of LCIA of the variation of current density and the process impact on the environment

The difference in contribution for electricity cost between scenarios J5 and J100 is too great to allow identification of the precise point from which the electricity contribution makes the scenario more environmentally damaging. A more precise comparative LCA study is therefore conducted. New current densities of 10, 15 and 25 A.m ${ }^{-2}$ were tested and the consequences on the BES unit inputs presented in Table 7. The environmental burdens caused by the process as a function of current densities are represented in Fig. 6 with narrower band current densities of 5 to 25 A.m².

Table 7. Additional date on the influence of the current density $(\mathrm{J})$ variation on BES inputs

\begin{tabular}{llllll}
\hline Scenario & $\mathbf{J}\left(\mathbf{A . m ^ { - 2 }}\right)$ & $\mathbf{\Delta V}(\mathbf{V})$ & $\mathbf{S}_{\mathbf{B E S}}\left(\mathbf{m}^{\mathbf{2}}\right)^{(\mathbf{1})}$ & $\mathbf{m}_{\text {elec }}(\mathbf{k g})^{(\mathbf{2})}$ & $\mathbf{E}(\mathbf{J})^{(\mathbf{3})}$ \\
\hline $\mathbf{J 1 0}$ & 10 & 0.97 & $4.27 \times 10^{4}$ & $7.69 \times 10^{3}$ & $1.31 \times 10^{13}$ \\
$\mathbf{J 1 5}$ & 15 & 1.06 & $2.85 \times 10^{4}$ & $5.13 \times 10^{3}$ & $1.42 \times 10^{13}$ \\
$\mathbf{J 2 5}$ & 25 & 1.23 & $1.71 \times 10^{4}$ & $3.08 \times 10^{3}$ & $1.65 \times 10^{13}$ \\
\hline
\end{tabular}

(1) surface of electrode; (2) mass of electrode; (3) electricity input of the BES

Fig. 6. Refined LCIA of the effect of current density variation by taking into account only the burdens of the BES materials and the electricity cost

Depending on which impact category is considered, the contribution to environmental impacts of the

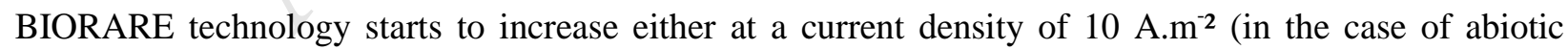
depletion, freshwater ecotoxicity, human toxicity), or at a current density of 15 A.m ${ }^{-2}$ (in the case of acidification, eutrophication, climate change, marine ecotoxicity and photochemical oxidation), or at a current density exceeding 25 A.m ${ }^{-2}$ (in the case of ozone layer depletion and terrestrial ecotoxicity). Under the last category, the environmental burdens are mostly related to the electrode production cost. Considering all these factors, the appropriate balance would be to set the current density of the BES between $10 \mathrm{~A} . \mathrm{m}^{-2}$ and $20 \mathrm{~A} \cdot \mathrm{m}^{-2}$ depending on the dominant pollution concern.

\subsection{The influence of the hydrolysis yield in the pre-treatment of the biowaste}

The hydrolysis yield represents the capacity of pre-treatment to breakdown the organic matter present in the biowaste feed stream. When this yield is relatively high (>50\%), the hydrolysis of waste is 
considered efficient. Consequently, less waste volume is needed to obtain the same required amount of VFA (see Table 4 ). However, at a low $10 \%$ yield meaning a low VFA content ( $\left.28 \mathrm{~g}_{\mathrm{DCO}} / \mathrm{l}\right)$, the hydrolysed subst from the BES bio-cathode (1,353 tonnes), (which is sent to the digestion unit), is almost eight times higher than that under the $80 \%$ yield conditions (169 tonnes). The potential environmental impact resulting from different hydrolysis yields are showed in Fig. 7. Scenario Y10, (10\% yield), presents the highest environmental burden in all impact categories. This decreases as the hydrolysis yield increases. This trend is due to the contribution of the AD digestion system. Compared to the scenario Y80, more waste is needed thus more substrate has to be treated in the digestion unit under scenario Y10, which generates more digestate to be spread but more biogas is produced for the cogeneration unit. As a result, higher air emissions linked to digestion, combustion and spreading processes are expected which fall when the hydrolysis yield increases.

On the other hand, the difference between the options is far less marked when considering the following categories: abiotic depletion, human toxicity and marine ecotoxicity. The main reason is that scenarios Y50 and Y80 require more electricity input than scenarios Y10 and Y20 because less energy is produced internally resulting from less biogas production.

The hydrolysis yield is a parameter which depends on the pre-treatment conditions and the raw biowaste composition, it is thus difficult to predict. From a LCA perspective, any hydrolysis yields above $50 \%$ would be of special interest in terms of the mitigation of environmental impacts.

Fig. 7. Comparative LCIA of the system as a function of the variation of hydrolysis yield

\subsection{Is it better to emit or to recycle $\mathrm{CO}_{2}$ ?}

The BIORARE process includes organic matter degradation in three distinct process units: the hydrolysis step, BES synthesis and AD digestion. These processes also generate a large amount of respiration gases, especially $\mathrm{CO}_{2}$. A $\mathrm{CO}_{2}$ recovery unit was added to the BIORARE scenario and the comparison of the latter with and without this option shown in Fig. 8.

Fig. 8. LCIA of succinic acid production compared with bioethanol production a) without and b) with $\mathrm{CO}_{2}$ recovery

Even at a low significance threshold, the recovery of $\mathrm{CO}_{2}$ does not provide obvious environmental benefits since the relative contribution of both scenarios is very similar. The biggest difference, (although still not significant), is observed for the option Management B with respect to climate change. Before any $\mathrm{CO}_{2}$ recovery, management $\mathrm{B}$ contributes the most amongst all three scenarios but it is the one showing a slightly reduced burden when $\mathrm{CO}_{2}$ recovery is added in. In the "management A" scenario, 6,430 tonnes of $\mathrm{CO}_{2}$ are recovered whereas the management scenarios $\mathrm{B}$ and $\mathrm{C}$ allow the recovery of 9,490 tonnes and 6,430 tonnes respectively. When a system generates more than one product, allocation is necessary in a LCA study. Economic allocation is applied for the BIORARE scenario (see Supporting Material) in order to apportion the environmental impacts between succinic acid and $\mathrm{CO}_{2}$ production. Consequently, the relative contribution of each product increases with the amount produced. As more $\mathrm{CO}_{2}$ is recovered in "management B" scenario, the $\mathrm{CO}_{2}$ allocation is higher in this case than in "management $\mathrm{A}$ " and "management C" scenarios, thus leading to a smaller allocation to succinic acid production.

\subsection{Eco-efficiency through biomolecule choice}

When the environmental benefit of a given scenario is less than zero, then it is considered to show a low eco-efficiency (EE) to no EE, as shown in Fig. 9. The production of succinic acid using BIORARE technology displays a low EE close the "no EE" zone with respect to the following impact categories: terrestrial ecotoxicity, abiotic depletion and ozone layer depletion. On the other hand, the French market share and $\Delta I$ value of BIORARE succinic acid make the BIORARE technology quite eco-efficient for six impact categories. The production of bioethanol using the BIORARE approach has no negative environmental impacts unlike the comparable production of biosuccinic acid. However, the market share of the BIORARE technology used to produce bioethanol would be very low (below $1 \%$ ). For this reason, 

EE.

The European market share case is not displayed here because the observations and conclusions are the same as for the French market share.

Fig. 9. Eco-efficiency comparison of the production of succinic acid and bioethanol on the French market if the BIORARE BES were to be implemented on all French AD plants treating biowaste (ADP: abiotic depletion potential; AP: acidification potential; EP: eutrophication potential; FEP: freshwater ecotoxicity potential; CC: climate change; HTP: human toxicity potential; MEP: marine ecotoxicity potential; ODP: ozone layer depletion potential; PCOP: photochemical oxidation; TEP: terrestrial ecotoxicity potential)

\subsection{Discussion}

Enhancing the productivity of the BES unit by increasing the current density also changes the environmental profile of the BIORARE technology. When the current density is at $5{\mathrm{~A} . \mathrm{m}^{2}}^{2}$ (scenario J5), the BES is considered as a low cost process because it requires less energy input compared to the other three scenarios. However the high quantity of electrode material makes it less beneficial to the environment regarding resource preservation. The LCIA results might change in either direction if the electrode material was changed, for example using stainless steel instead of graphite. The electrode material was not revealed to be the most significant factor in the study of current density variation. Indeed, the sensitivity analysis did point out that the energy efficiency of the BES system was a real issue when the current density had been increased. Therefore, the choice of the external electricity source has to be relevant in the study. In this study, power from the French grid is used. There are alternative options to avoid purchasing electricity from grid, such as the integration of solar panels in to the BES process (Nevin et al., 2010). Overall the sensitivity of the current density parameter shows that to ensure good environmental performance, the productivity may have to be compromised, thus revealing a conflict between environment and economic objectives.

The sensitivity analysis of the current density parameter showed certain variability in the BES unit. The latter is part of a whole system which includes the anaerobic digestion. The importance of the waste transformation was considered through a sensitivity analysis of the hydrolysis yield of biowaste within the hydrolysis unit. The experimental yield is approximately $20 \%$ which does not allow the sufficient production of biogas in the $\mathrm{AD}$ unit to supply the whole system in terms of electricity. In order to increase the electricity production, more substrate has to be sent to the digestion unit thus the hydrolysis yield has to be lower than $20 \%$. With this setup, less succinic acid is produced because of a lower provision of VFA content to the anodic compartment of the BES. Increasing the amount of succinic acid produced results from increasing the hydrolysis yield. However, this configuration implies producing less electricity, resulting in purchasing some from external sources. As observed in the case of the current density parameter, the sensitivity of the hydrolysis yield shows two conflicting effects. If the yields higher than $20 \%$ can be achieved, the type of efficiency (energy or production) should be well considered in advance. Thus strategies to enhance the BIORARE technology may boost its eco-efficiency by lowering the contribution to certain environmental impact categories such as abiotic depletion, terrestrial ecotoxicity and ozone layer depletion.

As well as testing the sensitivity of process input parameters, the sensitivity with respect to outputs was also considered. Indeed, high emissions of $\mathrm{CO}_{2}$ were identified during the inventory step. The benefit of avoiding such $\mathrm{CO}_{2}$ emissions to the atmosphere is modest in the case of BIORARE technology because the quantity of $\mathrm{CO}_{2}$ to be recovered is relatively small. It might not be worthwhile to recover this small amount of $\mathrm{CO}_{2}$ based on the argument that the technical requirements for capturing and purifying $\mathrm{CO}_{2}$ could be considerable. A contribution analysis was performed and is set out separately in the Supporting Material annexe. The environmental impact of the $\mathrm{CO}_{2}$ purification unit is barely noticeable when compared to that of the other process steps. If the amount of $\mathrm{CO}_{2}$ to be emitted or recovered was larger, it would be of interest to see if the benefit of recovery would then be significant considering the increased burdens of biogenic $\mathrm{CO}_{2}$ emissions and of the purification unit inputs/outputs. The interest of BIORARE

$$
\text { Comment citer ce document: }
$$


technology is to convert carbon (contained in biowaste) into energy through the production of biogas during the anaerobic digestion process and into high added value molecules in the microbial fuel cell. This sensitivity analysis focuses on the ways to reuse $\mathrm{CO}_{2}$ emissions to supply microbial fuel cell in one hand and to recover $\mathrm{CO}_{2}$ emissions for industry in the other hand. In these cases, the carbon is used and not sequestrated. Actually, it is necessary to produce a soil enricher like compost or biochar to sequestrate carbon in soil. The philosophy of BIORARE is simultaneously the use of carbon to improve the economic value of the product (energy or biomolecules) and the production of a digestate as an organic fertilizer.

The assessment of the eco-efficiency of the biomolecule choice shows that the best combination of environmental and economic performances is obtained by the production of biosuccinic acid for an intermediate market. This conclusion is the result of a theoretical approach for the calculation of ecoefficiency of the BIORARE technology. Indeed, this calculation should consider the quality of biowaste which influences the technological performance of the disintegration process, and the flexibility of the market for the acceptance of waste-based molecules which influences the economical performances. Despite these limitations, the production of waste-based molecules is promising for intermediate markets from an environmental point of view.

\section{Conclusions}

Many strategies and technologies have been developed to recycle organic wastes fitting in the concept of bio-economy. The concept of biorefineries that rely on bioelectrochemical systems are an attractive concept since it aims at producing useful chemical products from waste sources. Such a technology coupling a bioelectrosynthesis and an anaerobic digestion plant was modelled using a LCA methodology, in order to identify key environmentally sensitive design parameters and to select best implementation strategies, thus demonstrating how LCA approaches could be used to improve environmental performances of innovative processes. Sensitive parameters identified were the current density of the bioelectrosynthesis process and the hydrolysis yield during an initial pre-treatment of the waste. By testing the effect of these parameters, a balance between environmental benefit and good productivity was revealed. Separately, the recovery of $\mathrm{CO}_{2}$ emissions, turned out to be inconsequential. The environmental efficiency of the technology was tested by studying the eco-efficiency ratio which is based on the possible market share of the product and the environmental benefit. In the case of succinic acid production, good eco-efficiency was shown despite some trade-offs on environmental impacts: if production was switched to bioethanol, there was a poorer efficiency with no impacts trade-offs. This eco-design approach of an innovative process based on LCA and eco-efficiency calculation shows the potential of environmental assessment to be useful for the improvement of the environmental, technical and economical performances of a technology with a low TRL. This systemic approach could be performed to guide the choice of targeted biomolecules which should be produced and the key parameters of the innovative technologies.

\section{Acknowledgments}

The authors would like to thank the French National Research Agency for funding the BIORARE project within the "Biotechnology and bioresources - Investments for the future" call.

\section{References}

Ardente, F., Cellura, M., 2012. Economic Allocation in Life Cycle Assessment: The State of the Art and Discussion of Examples. J. Ind. Ecol. 16, 387-398. https://doi.org/10.1111/j.15309290.2011.00434.x

Azapagic, A., Millington, A., Collett, A., 2006. A Methodology for Integrating Sustainability Considerations into Process Design. Chem. Eng. Res. Des. 84, 439-452. https://doi.org/10.1205/cherd05007 
Barnett, H.J., Morse, C., 2013. Scarcity and Growth:The Economics of Natural Resource Availability. Routledge.

Bhatia, S.K., Joo, H.-S., Yang, Y.-H., 2018. Biowaste-to-bioenergy using biological methods - A minireview. Energy Convers. Manag 177, 640-660. https://doi.org/10.1016/j.enconman.2018.09.090

Bechthold, I., Bretz, K., Kabasci, S., Kopitzky, R., Springer, A., 2008. Succinic Acid: A New Platform Chemical for Biobased Polymers from Renewable Resources. Chem. Eng. Technol. 31, 647-654. https://doi.org/10.1002/ceat.200800063

Beegle, J. R., Borole, A. P., 2018. Energy production from waste: Evaluation of anaerobic digestion and bioelectrochemical systems based on energy efficiency and economic factors. Renew Sust Energ Rev 96, 343-351. https://doi.org/10.1016/j.rser.2018.07.057.

Biorare project [WWW Document], 2018. . Biorare Proj. URL https://biorare.irstea.fr/ (accessed 3.23.18).

Bygrave, S., Ellis, J., 2003. Policies to Reduce Greenhouse Gas Emissions in Industry - Successful Approaches and Lessons Learned: Workshop Report. OECD Environment Directorate and International Energy Agency.

Cao, Y., Zhang, R., Sun, C., Cheng, T., Liu, Y., Xian, M., Cao, Y., Zhang, R., Sun, C., Cheng, T., Liu, Y., Xian, M., 2013. Fermentative Succinate Production: An Emerging Technology to Replace the Traditional Petrochemical Processes, Fermentative Succinate Production: An Emerging Technology to Replace the Traditional Petrochemical Processes. BioMed Res. Int. BioMed Res. Int. 2013, 2013, e723412. https://doi.org/10.1155/2013/723412, 10.1155/2013/723412

Chemical industry awaits for bio-succinic acid potential [WWW Document], n.d. URL https://www.icis.com/ (accessed 10.4.17).

Cok, B., Tsiropoulos, I., Roes, A.L., Patel, M.K., 2014. Succinic acid production derived from carbohydrates: An energy and greenhouse gas assessment of a platform chemical toward a biobased economy. Biofuels Bioprod. Biorefining 8, 16-29. https://doi.org/10.1002/bbb.1427

Delhomme, C., Weuster-Botz, D., Kühn, F.E., 2009. Succinic acid from renewable resources as a $\mathrm{C}_{4}$ building-block chemical-a review of the catalytic possibilities in aqueous media. Green Chem 11, 13-26. https://doi.org/10.1039/B810684C

De Vrieze, J., Arends, J.B.A., Verbeeck, K., Gildemyn, S., Rabaey, K., 2018.Interfacing anaerobic digestion with (bio)electrochemical systems: Potentials and challenges. Water Res 146, 244-255. https://doi.org/10.1016/j.watres.2018.08.045.

Du, C., Lin, S.K.C., Koutinas, A., Wang, R., Dorado, P., Webb, C., 2008. A wheat biorefining strategy based on solid-state fermentation for fermentative production of succinic acid. Bioresour. Technol. 99, 8310-8315. https://doi.org/10.1016/j.biortech.2008.03.019

Escamilla-Alvarado, C., Poggi-Varaldo, H.M., Ponce-Noyola, M.T., 2017. Bioenergy and bioproducts from municipal organic waste as alternative to landfilling: a comparative life cycle assessment with prospective application to Mexico. Environ Sci Pollut Res 24, 25602-25617. https://10.1007/s11356-016-6939-z

European Commission, 2014. Horizon 2020, work programme $2014-2015$.

European Commission, 2015. Closing the Loop - An EU Action Plan for the Circular Economy, $\operatorname{COM}(2015) 614$ final. Communication from the commission to the European Parliament, the council, the european economic and social committee and the committee of the regions, Brussels, Belgium.

European Commission, 2010. International Reference Life Cycle Data System (ILCD) Handbook Framework and Requirements for Life Cycle Impact Assessment Models and Indicators. First edition. Publications Office of the European Union, Luxembourg.

Flach, B., Lieberz, S., Rondon, M., Williams, B., Wilson, C., 2016. EU Biofuels Annual 2016 (No. NL6021). USDA Foreign Agricultural Service.

Foley, J.M., Rozendal, R.A., Hertle, C.K., Lant, P.A., Rabaey, K., 2010. Life Cycle Assessment of HighRate Anaerobic Treatment, Microbial Fuel Cells, and Microbial Electrolysis Cells. Environ. Sci. Technol. 44, 3629-3637. https://doi.org/10.1021/es100125h

Fouilland, E., Vasseur, C., Leboulanger, C., 2014. Coupling algal biomass production and anaerobic digestion: Production assessment of some native temperate and tropical microalgae. Biomass Bioenergy 70, 564-569. https://10.1016/j.biombioe.2014.08.027

Foulet, A., Bouchez, T., Desmond-Le Quéméner, E., Giard, L., Renvoisé, L., Aissani, L., 2018. Life cycle assessment of a bioelectrochemical system as a new technological platform for biosuccinic acid production from waste. Environ Sci Pollut Res, 1-18. https://doi.org/10.1007/s11356-018-3530-9

GaBi Databases: GaBi Software [WWW Document], n.d. URL http://www.gabisoftware.com/international/databases/gabi-databases/ (accessed 5.16.18). 
Gargalo, C.L., Carvalho, A., Gernaey, K.V., Sin, G., 2017. Optimal Design and Planning of GlycerolBased Biorefinery Supply Chains under Uncertainty. Ind. Eng. Chem. Res. 56, 11870-11893. https://doi.org/10.1021/acs.iecr.7b02882

He, M., Sun, Y., Zou, D., Yuan, H., Zhu, B., Li, X., Pang, Y., 2012. Influence of Temperature on Hydrolysis Acidification of Food Waste. Procedia Environ. Sci., The Seventh International Conference on Waste Management and Technology (ICWMT 7) 16, 85-94. https://doi.org/10.1016/j.proenv.2012.10.012

Heijungs, R., Guinée, J.B., Huppes, G., Lankreijer, R.M., Udo de Haes, H.A., Wegener Sleeswijk, A., Ansems, A.M.M., Eggels, P.G., van Duin, R., de Goede, H.P., 2001. Environmental life cycle assessment of products: guide and backgrounds (Part 2). In: Environmental Management - Life Cycle Assessment - Principles and Framework.

Helminen, R.-R., 2000. Developing tangible measures for eco-efficiency: the case of the Finnish and Swedish pulp and paper industry. Bus. Strategy Environ. 9, 196-210. https://doi.org/10.1002/(SICI)1099-0836(200005/06)9:3<196::AID-BSE240>3.0.CO;2-O

Hetherington, A.C., Borrion, A.L., Griffiths, O.G., McManus, M.C., 2014. Use of LCA as a development tool within early research: Challenges and issues across different sectors. Int. J. Life Cycle Assess. 19, 130-143. https://doi.org/10.1007/s11367-013-0627-8

ISO, 2006a. ISO 14040:2006 - Environmental management - Life cycle assessment - Principles and framework. International Organization for Standardization (ISO), Geneva, Switzerland.

ISO, 2006b. ISO 14044:2006 - Environmental management - Life cycle assessment - Requirements and guidelines. International Organization for Standardization (ISO), Geneva, Switzerland.

Jos, G.J.O., Janssens-Maenhout, G., Muntean, M., Peters, J.A.H.W., 2016. Trends in global CO2emissions. 2016 Report. PBL Neth. Environ. Assess. Agency 86.

Kuosmanen, T., Kortelainen, M., 2005. Measuring Eco-efficiency of Production with Data Envelopment Analysis. https://doi.org/10.1162/108819805775247846

Lam, K.F., Leung, C.C.J., Lei, H.M., Lin, C.S.K., 2014. Economic feasibility of a pilot-scale fermentative succinic acid production from bakery wastes. Food Bioprod. Process. 92, 282-290. https://doi.org/10.1016/j.fbp.2013.09.001

Lovley, D.R., 2006. Microbial fuel cells: novel microbial physiologies and engineering approaches. Curr. Opin. Biotechnol., Environmental biotechnology/Energy biotechnology 17, 327-332. https://doi.org/10.1016/j.copbio.2006.04.006

Manfredi, S., Pant, R., European Commission, Joint Research Centre, Institute for Environment and Sustainability, 2011. Supporting environmentally sound decisions for bio-waste management: a practical guide to Life Cycle Thinking (LCT) and Life Cycle Assessment (LCA). Publications Office, Luxembourg.

Mankins, J.C., 1995. Technology readiness levels. White Pap. April 6.

McCarty, P.L., 1964. Anaerobic waste treatment fundamentals. Public Works 95, 107-112.

McKinlay, J.B., Vieille, C., Zeikus, J.G., 2007. Prospects for a bio-based succinate industry. Appl. Microbiol. Biotechnol. 76, 727-740. https://doi.org/10.1007/s00253-007-1057-y

Moscoviz, R., de Fouchécour, F., Santa-Catalina, G., Bernet, N., Trably, E., 2017. Cooperative growth of Geobacter sulfurreducens and Clostridium pasteurianum with subsequent metabolic shift in glycerol fermentation. Sci. Rep. 7, 44334. https://doi.org/10.1038/srep44334

Nallathambi Gunaseelan, V., 1997. Anaerobic digestion of biomass for methane production: A review. Biomass Bioenergy 13, 83-114. https://doi.org/10.1016/S0961-9534(97)00020-2

Nevin, K.P., Woodard, T.L., Franks, A.E., Summers, Z.M., Lovley, D.R., 2010. Microbial Electrosynthesis: Feeding Microbes Electricity To Convert Carbon Dioxide and Water to Multicarbon Extracellular Organic Compounds. mBio 1. https://doi.org/10.1128/mBio.00103-10

Overcash, M., Li, Y., Griffing, E., Rice, G., 2007. A life cycle inventory of carbon dioxide as a solvent and additive for industry and in products. J. Chem. Technol. Biotechnol. 82, 1023-1038. https://doi.org/10.1002/jctb.1747

Pant, D., Singh, A., Van Bogaert, G., Gallego, Y.A., Diels, L., Vanbroekhoven, K., 2011. An introduction to the life cycle assessment (LCA) of bioelectrochemical systems (BES) for sustainable energy and product generation: Relevance and key aspects. Renew. Sustain. Energy Rev. 15, 1305-1313. https://doi.org/10.1016/j.rser.2010.10.005

Rabaey, K., Rozendal, R.A., 2010. Microbial electrosynthesis — revisiting the electrical route for microbial production. Nat. Rev. Microbiol. 8, 706-716. https://doi.org/10.1038/nrmicro2422

Reddy, M.V., ElMekawy, A., Pant, D., 2018. Bioelectrochemical synthesis of caproate through chain elongation as a complementary technology to anaerobic digestion. Biofuels Bioprod Biorefining. doi: $10.1002 / b b b .1924$ 
Ras, M., Lardon, L., Bruno, S., Bernet, N., Steyer, J.-PA, 2011SExperimental study on a coupled process of production and anaerobic digestion of Chlorella vulgaris. Bioresour Technol 102, 200-206. https://10.1016/j.biortech.2010.06.146

Shibasaki, M., Fischer, M., Barthel, L., 2007. Effects on Life Cycle Assessment - Scale Up of Processes, in: Takata, S., Umeda, Y. (Eds.), Advances in Life Cycle Engineering for Sustainable Manufacturing Businesses. Springer London, pp. 377-381. https://doi.org/10.1007/978-1-84628935-4_65

Silveira, E.A., Caldeira-Pires, A., Luz, S.M., Silveira, C.M., 2017. Mass and energy allocation method analysis for an oil refinery characterization using multi-scale modeling. Int. J. Life Cycle Assess. 22, 1815-1822. https://doi.org/10.1007/s11367-017-1369-9

SINOE® déchets [WWW Document], n.d. URL http://www.sinoe.org/ (accessed 4.18.18).

Smith, R., 2015. Regulation (EC) No 764/2008 of the European Parliament and of the Council - laying down health rules as regards animal by-products and derived products not intended for human consumption and repealing Regulation (EC) No 1774/2002 (Animal by-products Regulation), in: Core EU Legislation. Macmillan Education UK, London, pp. 183-186. https://doi.org/10.1007/978-1-137-54482-7_19

Swan, L.G., Ugursal, V.I., 2009. Modeling of end-use energy consumption in the residential sector: A review of modeling techniques. Renew. Sustain. Energy Rev. 13, 1819-1835.

Thambimuthu, K., Davison, J., Gupta, M., 2002. IPCC Workshop on Carbon Capture and Storage.

Thinkstep, 2016. GaBi Software-System and Database for the Life Cycle Engineering. LeinfeldenEchterdingen, Germany.

Tsang, M., Sonnemann, G.W., Philippot, G., Aymonier, C., 2014. Supercritical \& Sustainable Synthesis of Nanoparticles?, in: EcoBalance 2014.

Weastra, 2012. Determination of market potential for selected platform chemicals - EU project BioConSept. weastra, s.r.o.

Wernet, G., Bauer, C., Steubing, B., Reinhard, J., Moreno-Ruiz, E., Weidema, B., 2016. The ecoinvent database version 3 (part I): overview and methodology. Int. J. Life Cycle Assess. 21, 1218-1230. https://doi.org/10.1007/s11367-016-1087-8

Yan, Q., Zhao, M., Miao, H. et al, 2010. Coupling of the hydrogen and polyhydroxyalkanoates (PHA) production through anaerobic digestion from Taihu blue algae. Bioresour Technol 101,45084512. https://10.1016/j.biortech.2010.01.073 


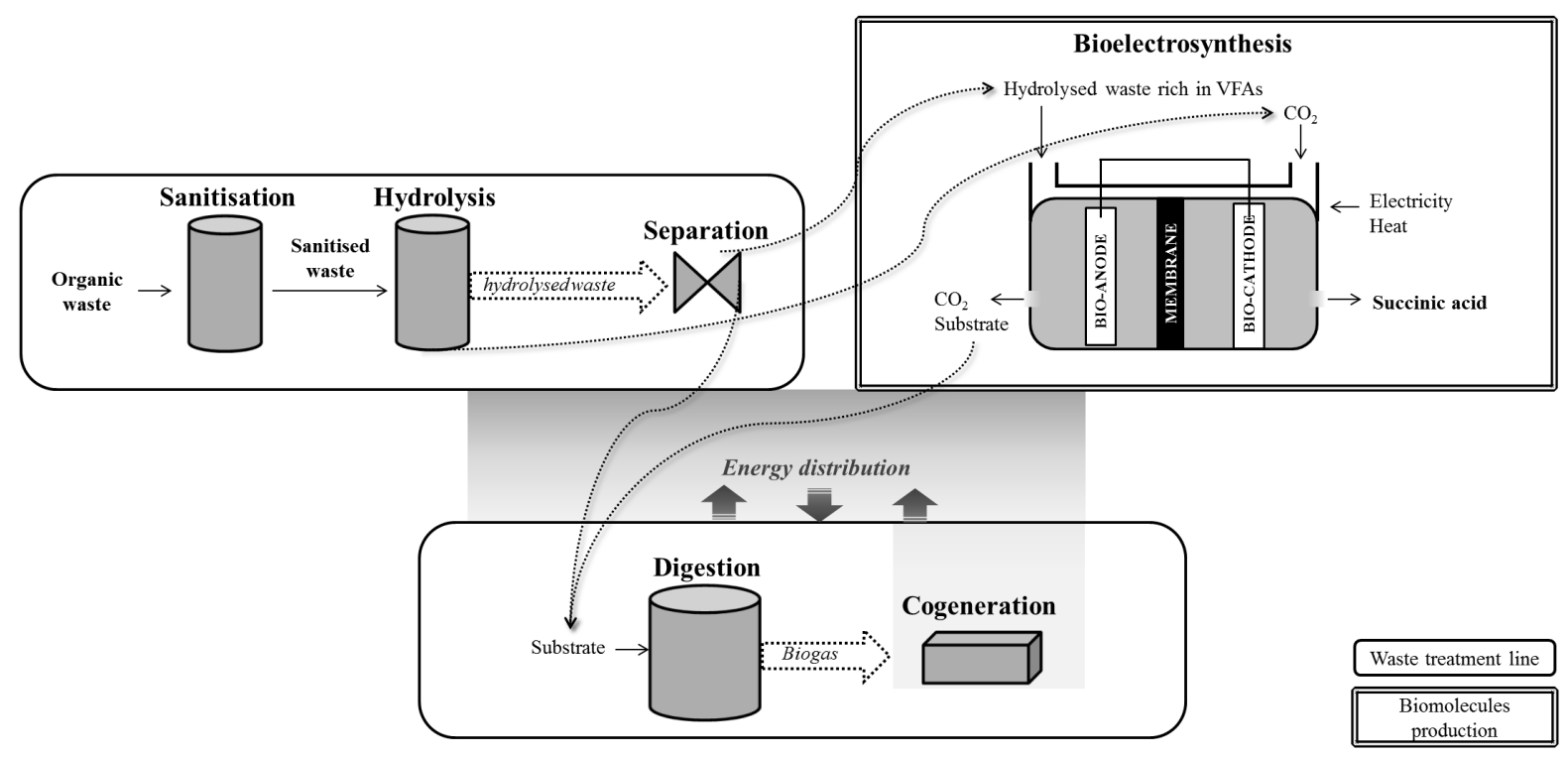




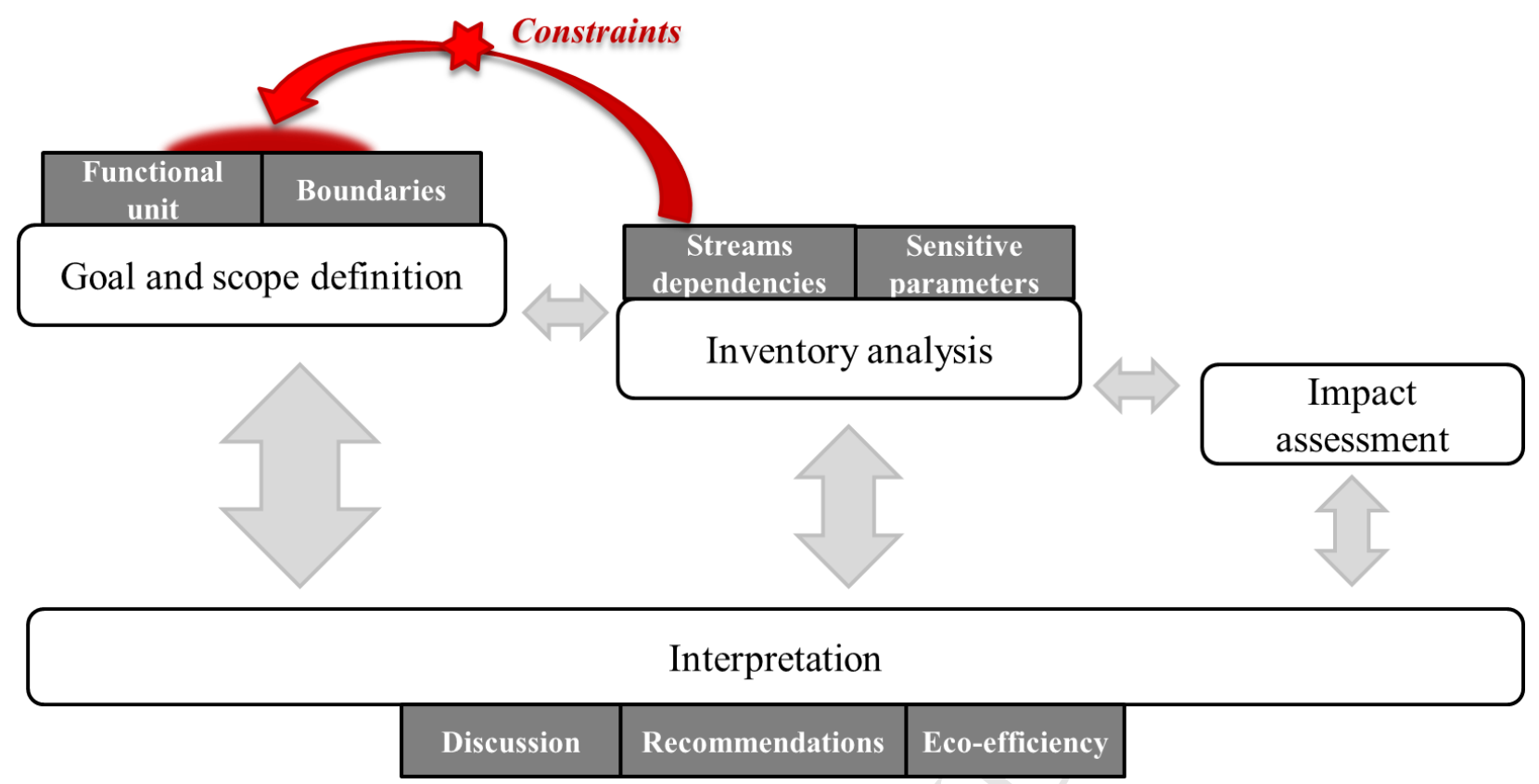




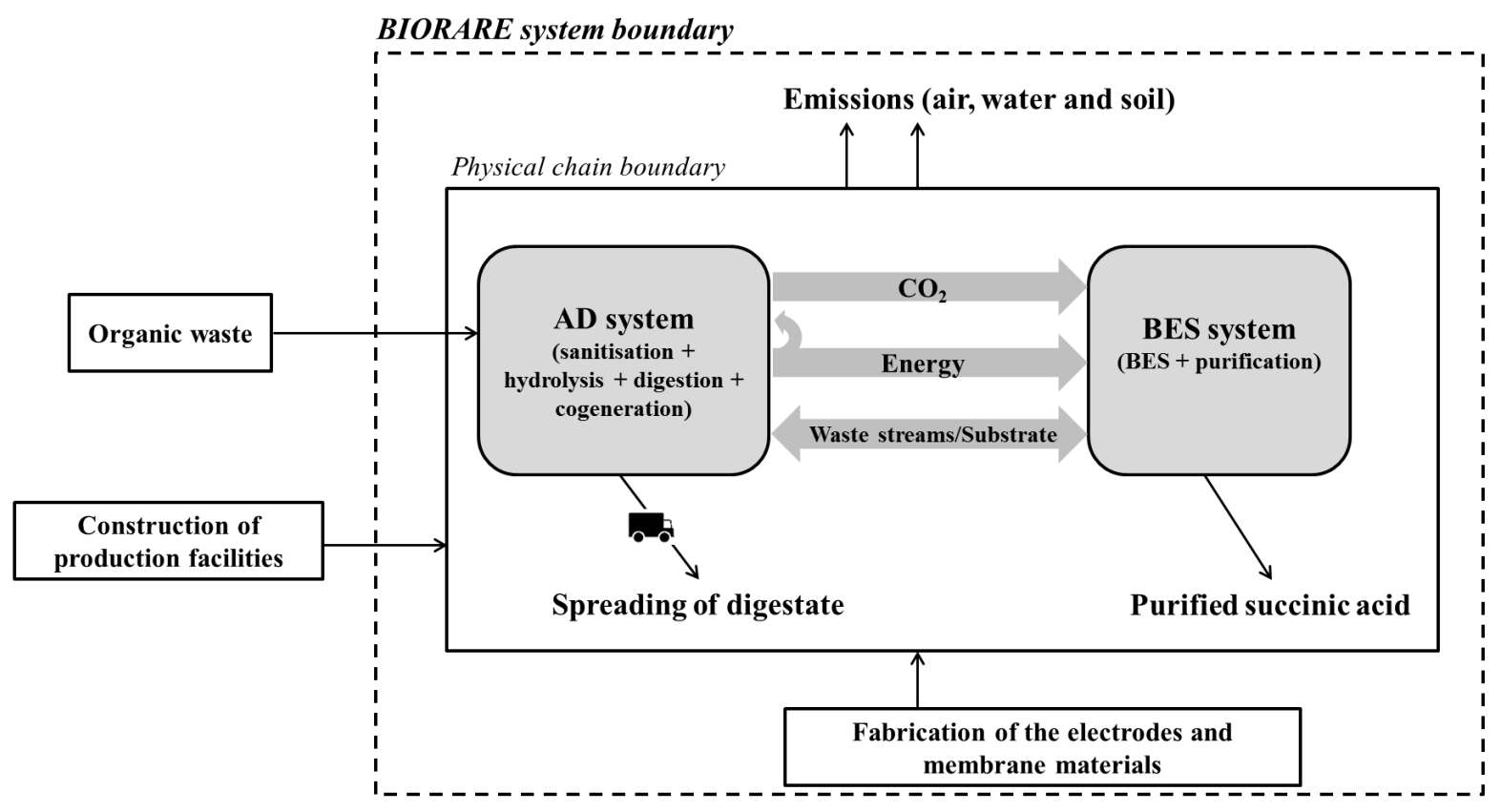




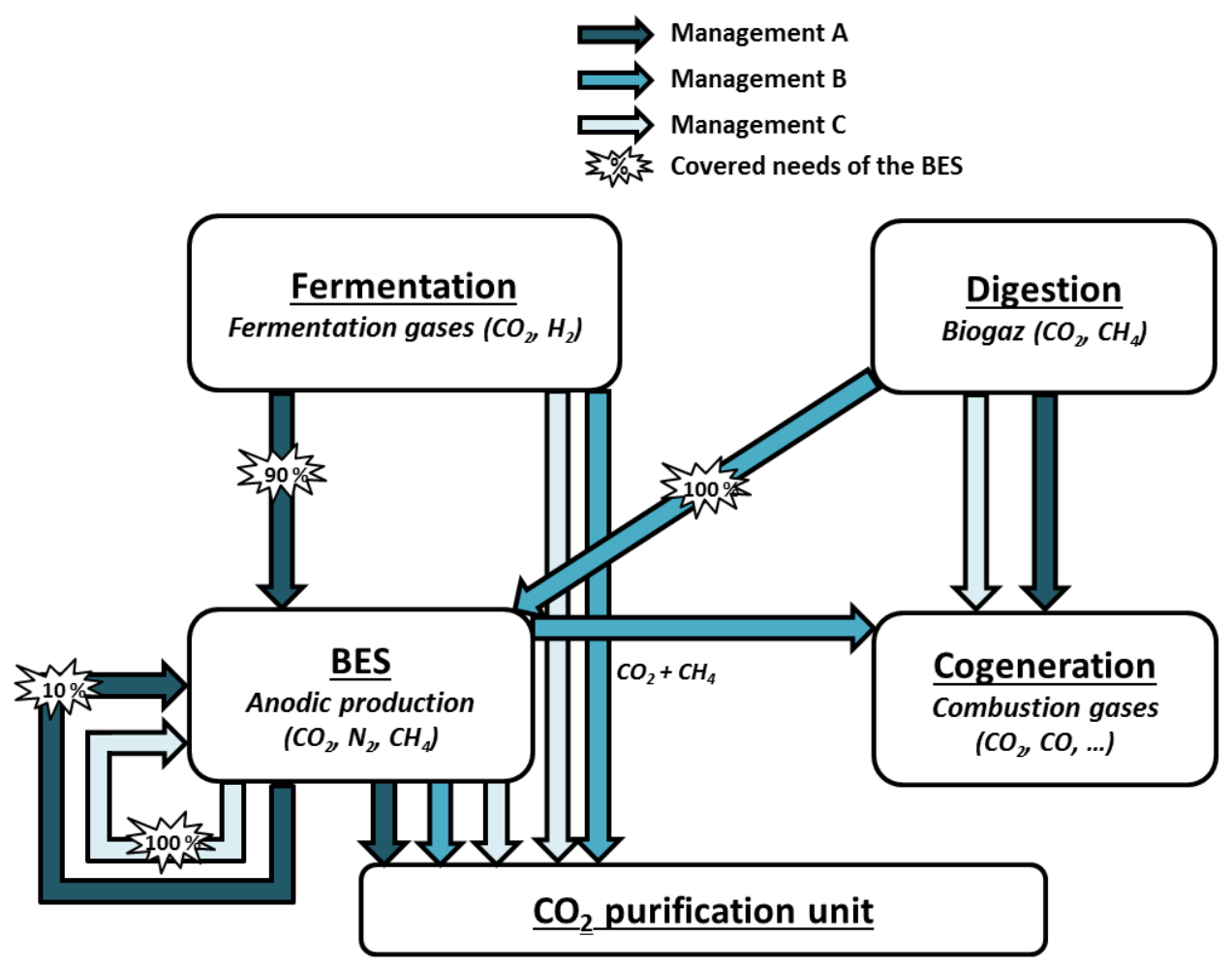




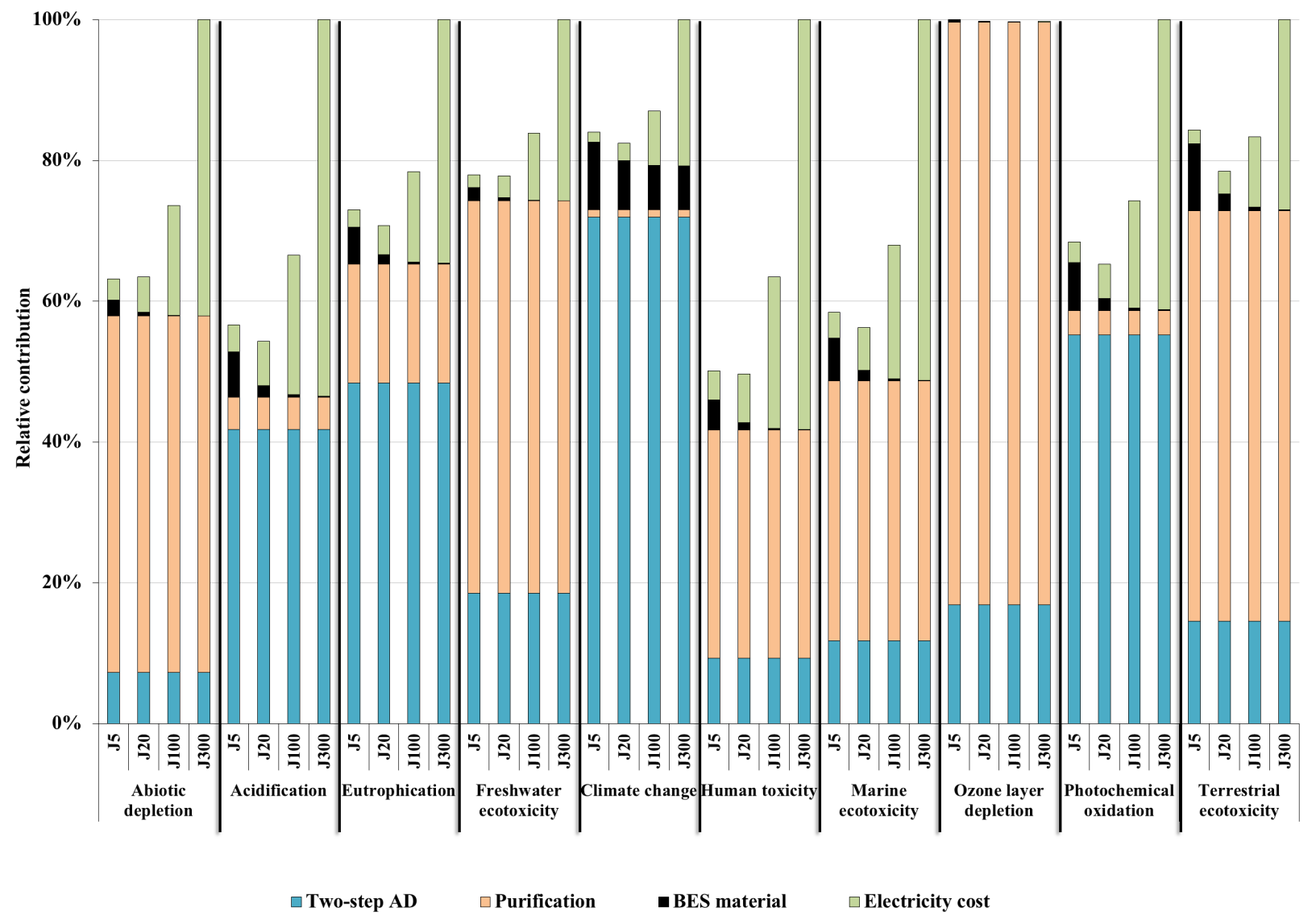




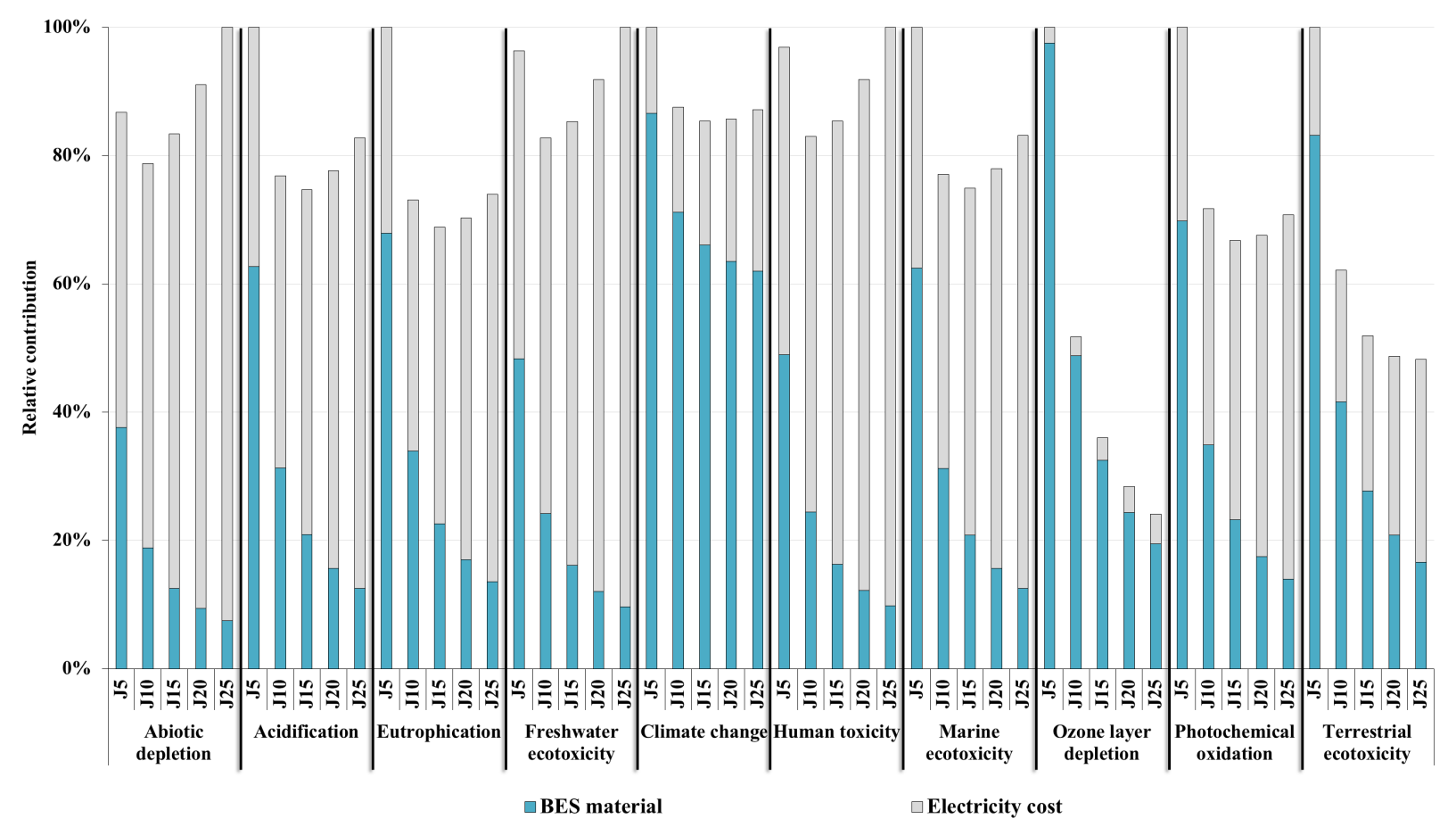




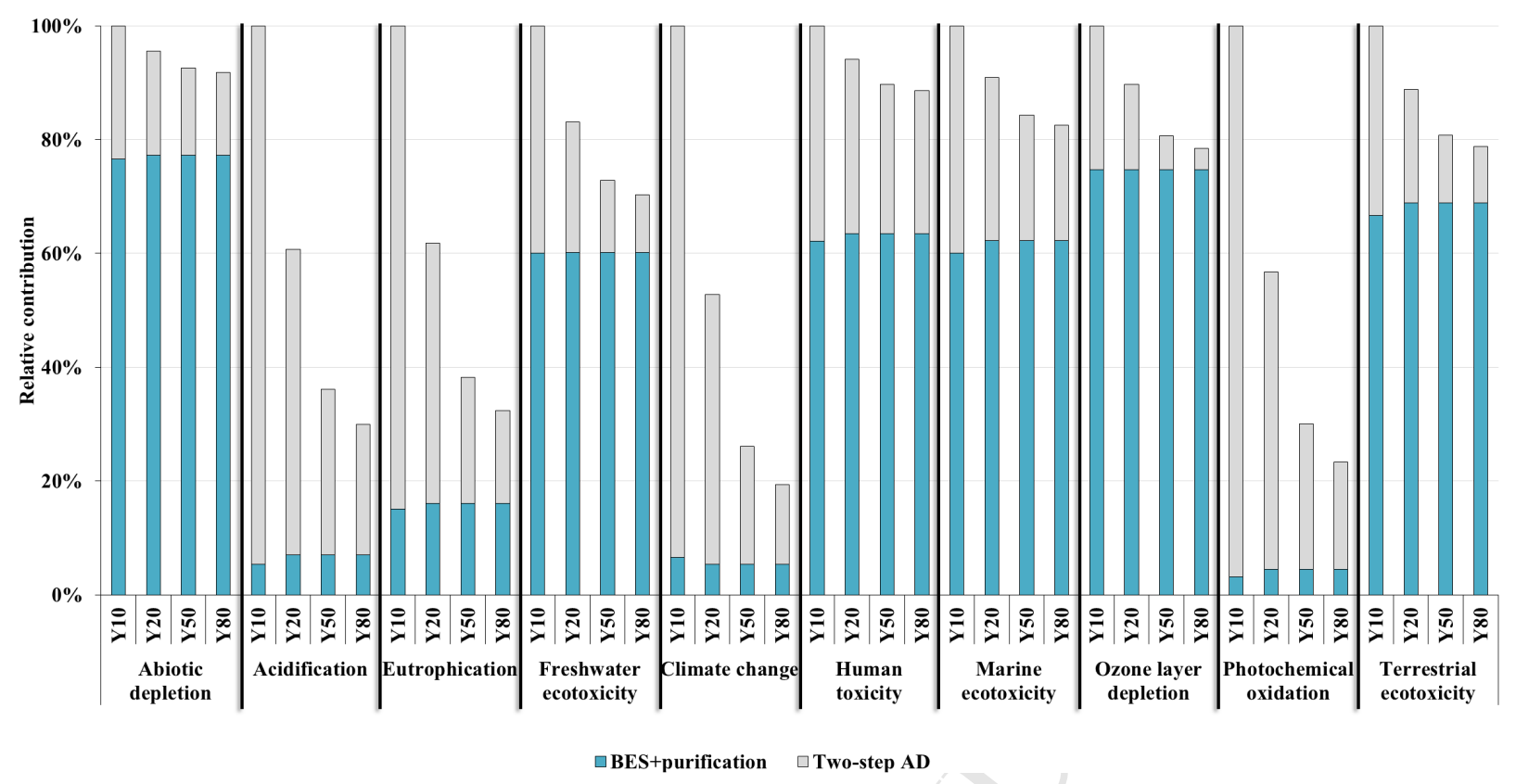




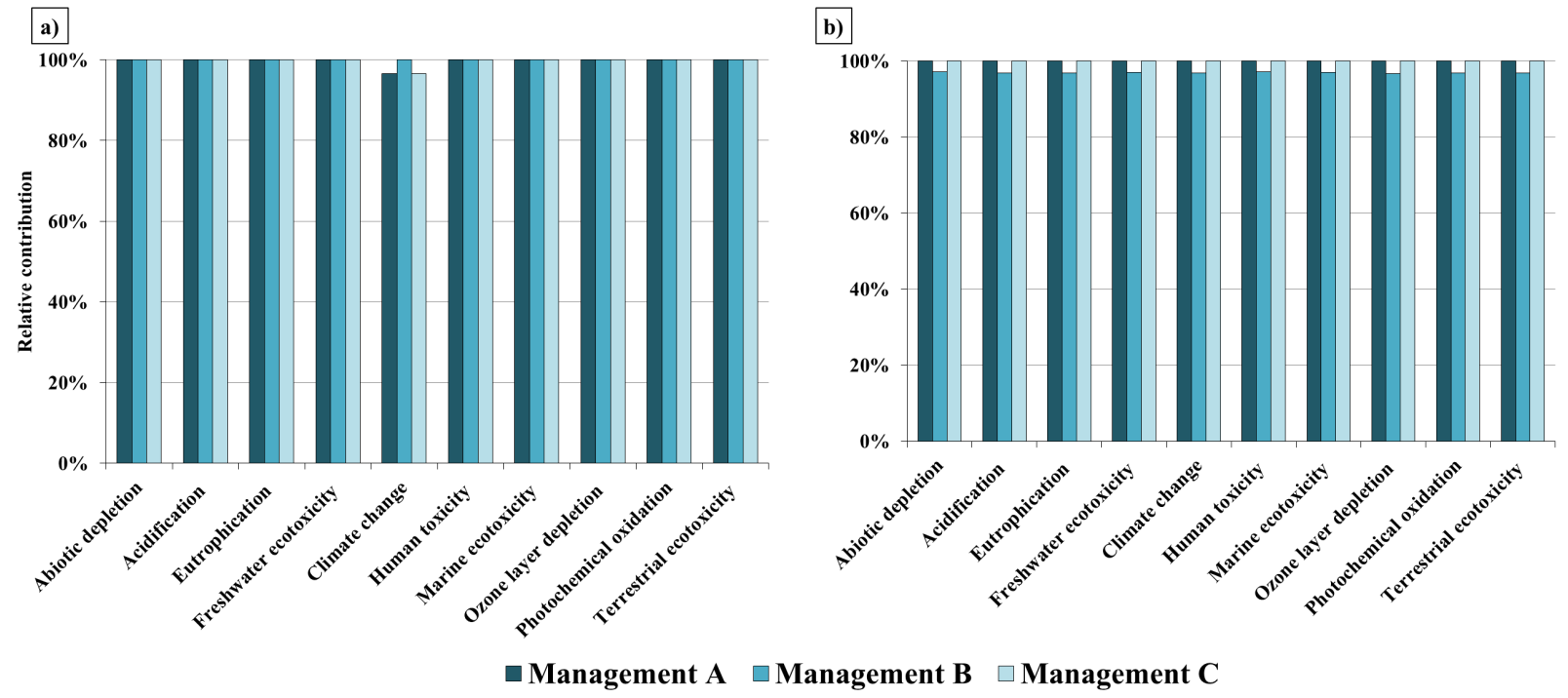




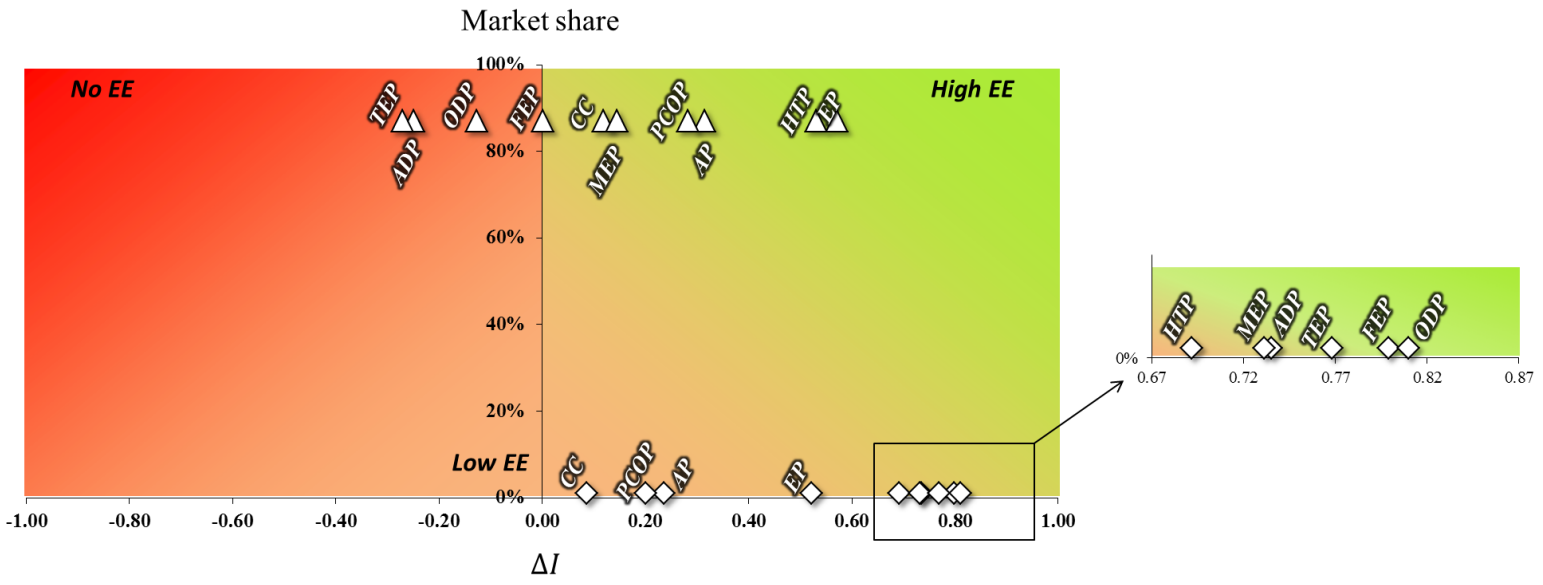

$\triangle$ Production of biosuccinic acid through the BIORARE BES unit coupled with the French AD plants

$\diamond$ Production of bioethanol through the BIORARE BES unit coupled with the French AD plants 


\section{Highlights}

- Environmental biorefinery can produce bio-succinic acid from organic wastes

- Eco-design through life cycle assessment helps identifying sensitive parameters

- Trade-offs exist between production efficiency (set of technical parameters to optimize the production) and environmental burdens 